A. 462 DP-1478

MASTER MASTER

\title{
PREDICTION OF STRESS CORROSION OF CARBON STEEL BY NUCLEAR PROCESS LIQUID WASTES
}

R. S. ONDREJCIN 



\section{DISCLAIMER}

This report was prepared as an account of work sponsored by an agency of the United States Government. Neither the United States Government nor any agency Thereof, nor any of their employees, makes any warranty, express or implied, or assumes any legal liability or responsibility for the accuracy, completeness, or usefulness of any information, apparatus, product, or process disclosed, or represents that its use would not infringe privately owned rights. Reference herein to any specific commercial product, process, or service by trade name, trademark, manufacturer, or otherwise does not necessarily constitute or imply its endorsement, recommendation, or favoring by the United States Government or any agency thereof. The views and opinions of authors expressed herein do not necessarily state or reflect those of the United States Government or any agency thereof. 


\section{DISCLAIMER}

Portions of this document may be illegible in electronic image products. Images are produced from the best available original document. 


\section{PREDICTION OF STRESS CORROSION OF CARBON STEEL BY NUCLEAR PROCESS LIQUID WASTES}

by

R. S. Ondrejcin

Approved by

R. T. Huntoon, Research Manager Nuclear Materials Division

Publication Date: August 1978

$$
\begin{aligned}
& \text { This report was prepared as an account of work } \\
& \text { sponsored by the United States Government Netther the } \\
& \text { Unted States nor the United States Department of } \\
& \text { Energy, nor any of then employees, nor any of their } \\
& \text { contractors, subcontractors, or their employees, makes } \\
& \text { any warranty, express or irnpled, or assumes any legal } \\
& \text { lability or responsiblinty for the accuracy, completeness } \\
& \text { or usefulness of any information, apparatus, product or } \\
& \text { process disclosed, or represents that its use would not } \\
& \text { infruge prvately owned nghts }
\end{aligned}
$$


Radioactive liquid wastes are produced as a consequence of processing fuel from Savannah River Plant (SRP) production reactors. These wastes are stored in mild steel waste tanks, some of which have developed cracks from stress corrosion. A laboratory test was developed to determine the relative agressiveness of the wastes for stress corrosion cracking of mild steel. Tensile samples were strained to fracture in synthetic waste solutions in an electrochemical cell with the sample as the anode. Crack initiation is expected if total elongation of the steel in the test is less than its uniform elongation in air. Cracking would be anticipated in a plant waste tank if solution conditions were equivalent to test conditions that cause a total elongation that is less than uniform elongation.

On the basis of data from two statistically designed experiments, a response surface equation was derived that relates elongation of a mild steel (ASTM A 285-B) in this test to the combined effect of four independent variables of the waste solution including temperature, $\mathrm{NO}_{3}^{-}, \mathrm{NO}_{2}^{-}$, and $\mathrm{OH}^{-}$. Elongation in the electrochemical tensile test, as a measure of the likelihood of stress corrosion cracking, can be calculated from the waste compositions to within an average of $8 \%$ of the measured values.

The electrochemical tensile tests showed that the supernates in salt receiver tanks at SRP have the least aggressive compositions, and wastes newly generated during fuel reprocessing have the most aggressive ones. Test data also verified that ASTM A 516-70 steel used in the fabrication of the later design waste tanks is less susceptible to cracking than the ASTM A 285-B steel used in earlier designs.

The electrochemical tensile test was subsequently used as one of the bases for establishing limits on the composition of the stored wastes. 


\section{CONTENTS}

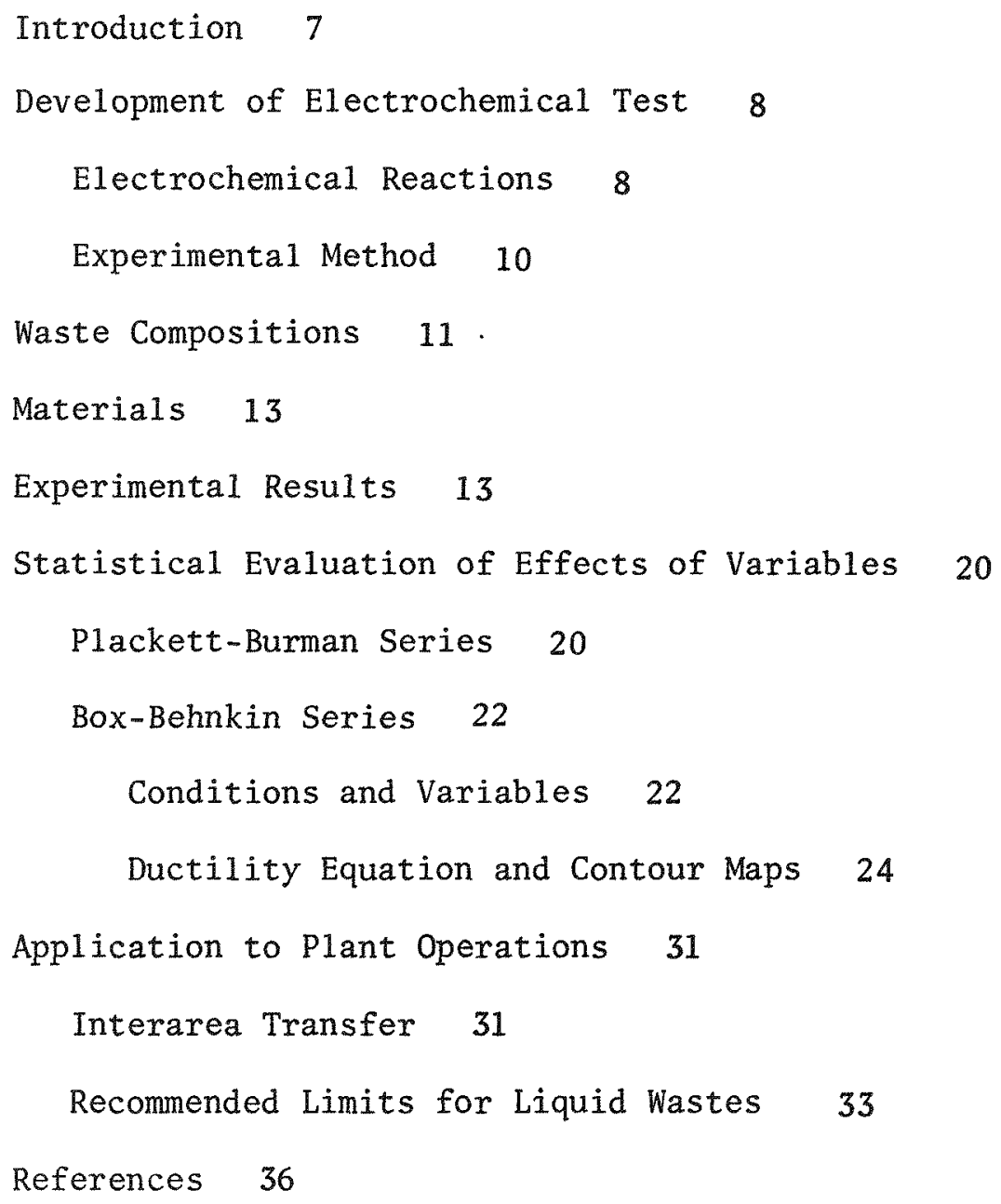




\section{LIST OF TABLES}

1. Effects of High-Heat Waste Constituents on Stee1 Corrosion 11

2. Plant Synthetic Test Solutions Based on Analyses 12

3. Compositions of Test Alloys 15

4. Tensile Properties in Electrochemical Tensile Test at $100^{\circ} \mathrm{C}$ and $0.5 \mathrm{~mA} / \mathrm{cm}^{2} \quad 15$

5. Relative Tensile Properties of A 285-B Stee1 in $221-\mathrm{H}$ Waste at $0.2 \mathrm{~mA} / \mathrm{cm}^{2} \quad 18$

6. Plackett-Burman Variables and Constants 21

7. Factorial and Box-Behnkin Designs 23

8. Box-Behnkin Conditions 24

9. Results of Electrochemical Tensile Test at $100^{\circ} \mathrm{C} 33$

10. Recommended Limits for Liquid Wastes 34 


\section{LIST OF FIGURES}

1. Electrochemical Tensile Test Equipment 10

2. Longitudinal Microstructure of A 285-B and A 516-70 Carbon Steels 14 .

3. Tensile Specimens of A 285-B Steel Tested in Various Media 16

4. Intergranular Cracking of A 285-B Steel in ConstantCurrent Tensile Test 17

5. Electrochemical Tensile Test: Variation of Strength With Hydroxide Concentration of A $285-\mathrm{B}$ Steel, $100^{\circ} \mathrm{C}$, $0.2 \mathrm{~mA} / \mathrm{cm}^{2} \quad 17$

6. Fracture Characteristics of A $285-\mathrm{B}$ Stee1 in $0.2 \mathrm{~mA} / \mathrm{cm}^{2}$ Tensile Test 19

7. Stylized Stress-Strain Curve 21

8. Elongation of A 285-B Mild Steel vs. Hydroxide Concentration in $\mathrm{HHW}, 100^{\circ} \mathrm{C}, 0.0 \mathrm{M} \mathrm{NO}_{2}^{-} 26$

9. Contour Map of Elongation of A 285-B Steel in Electrochemical Tensile Test, $100^{\circ} \mathrm{C}, 0.0 \mathrm{M} \mathrm{NO}-27$

10. Contours of $13 \%$ Elongation at Various Temperatures Nitrate Concentrations 28

11. Operationa1 Contour Map, $100^{\circ} \mathrm{C}, 0.0 \mathrm{M} \mathrm{NO}-29$

12. Operationa 1 Contour Map, $50^{\circ} \mathrm{C}, 0.0 \mathrm{M} \mathrm{NO}-29$

13. Equation 5 Depicted at $13 \%$ Elongation and $3.5 \mathrm{M}$ Nitrate $\quad 30$

14. Waste Compositions in Tanks $11 \mathrm{H}$ and $12 \mathrm{H}$ Compared to $13 \%$ Elongation Boundaries; Contours at $4.0 \mathrm{M} \mathrm{NO}_{3}^{-} 32$

15. Comparison of Electrochemical Tensile Test With WedgeOpening-Loaded Specimens in $5 \mathrm{M} \mathrm{NaNO}_{3}$ at $97^{\circ} \mathrm{C} \quad 35$ 



\section{PREDICTION OF STRESS CORROSION OF CARBON STEEL BY NUCLEAR PROCESS LIQUID WASTES}

\section{INTRODUCTION}

Radioactive wastes from reprocessing of nuclear fuel are stored in large near-surface mild stee1 tanks. The high-heat waste (HHW) tanks have volumes of 0.75 to 1.3 million gallons. The primary vessel is contained within a secondary steel pan which is in turn supported by an outer concrete shell. Detailed descriptions of the various tank designs are given in Reference 1.

A study was undertaken to identify solution compositions and temperatures that are conducive to nitrate stress corrosion cracking. The results have provided a technical basis for guiding waste management operations to protect the integrity of tanks used for storing radioactive waste.

SRP has two fuel reprocessing plants: the $F$ Area plant uses the Purex process to separate plutonium from uranium metal targets; and the $\mathrm{H}$ Area plant uses the HM process to recover enriched uranium from aluminum-uranium alloy fuel. Both processes include acid dissolution of fuel or targets containing the radioactive fission products followed by solvent extraction of products. The acidic wastes are made basic by adding $\mathrm{NaOH}$ in the separations buildings $(221-\mathrm{F}$ and $221-\mathrm{H})$ before waste solutions are pumped to one of the tank farms.

Wastes from the reprocessing plants are initially of different compositions, e.g., $\mathrm{H}$ Area waste contains more $\mathrm{NO}_{3}^{-}$and less $\mathrm{OH}^{-}$. Also, the average $\left[\mathrm{NO}_{3}^{-}\right] /\left[\mathrm{NO}_{2}^{-}\right]$ratio is 23 in $\mathrm{H}$ Area and $\sim 1$ in $F$ Area. As the solutions are aged and evaporated to reduce the liquid volume by crystallization of dissolved salts, the supernates remaining in the two areas tend to approach the same range of compositions. ${ }^{2}$

The electrochemical behavior of synthetic wastes had previously been shown to be equivalent to that of actual wastes so that laboratory studies with synthetic solutions could be expected to give results that were meaningful to plant operations. ${ }^{2}$ However, in previous experimental work, standard stress corrosion specimens did not crack in actual wastes probably because the samples were not sufficiently susceptible to cracking in a reasonable time period. A new experimental method for studying stress corrosion cracking was therefore desired. The method and results are described in this report. 


\section{DEVELOPMENT OF ELECTROCHEMICAL TENSILE TEST}

\section{Electrochemical Reactions}

During corrosion in nitrate solutions, carbon steel is proposed $^{3}$ to react anodically by

$$
3 / 4 \mathrm{Fe}+\mathrm{H}_{2} \mathrm{O} \rightarrow 1 / 4 \mathrm{Fe}_{3} \mathrm{O}_{4}+2 \mathrm{H}^{+}+2 \mathrm{e}^{-} \text {. }
$$

Probably at least two cathodic reactions take place with the following results:

$$
\mathrm{NO}_{3}^{-}+\mathrm{H}_{2} \mathrm{O}+2 \mathrm{e}^{-} \rightarrow \mathrm{NO}_{2}^{-}+2 \mathrm{OH}^{-} \text {. }
$$

The $\mathrm{H}^{+}$produced in the anodic reaction and the $\mathrm{OH}^{-}$produced in the cathodic reaction do not combine because the anode and cathode are separated. The anode is at the tip of a crack or the bottom of a pit, while the cathode may be the walls of the crack or the edge of the pit. As the reactions proceed, the anode becomes more acidic and the cathode becomes more basic.

Work at the Naval Research Laboratory (NRL) has shown that in stress corrosion cracking of a number of high-strength steels the tip of the crack becomes acidic, ${ }^{4}$ as inferred from Equation 1. Measurement showed the solutions at the crack tip to have a $\mathrm{pH}$ of 3.5 consistently. NRL concluded that the $\mathrm{pH}$ was controlled by the hydrolysis of the ferrous ion, i.e., the reaction

$$
\mathrm{Fe}^{+2}+\mathrm{HOH} \rightarrow \mathrm{Fe}(\mathrm{OH})^{+}+\mathrm{H}^{+}
$$

was controlling. In aqueous solutions, the hydrolysis constant for this reaction is $\left[\mathrm{Fe}(\mathrm{OH})^{+}\right]\left[\mathrm{H}^{+}\right] /\left[\mathrm{Fe}^{+2}\right]=1 \times 10^{-7}$. Since $\mathrm{Fe}(\mathrm{OH})^{+}$and $\mathrm{H}^{+}$are equimolar, The numerator becomes $\left[\mathrm{H}^{+}\right]^{2}$. Consequently, at the crack tip,

$$
\mathrm{pH}=-\log \left[\mathrm{H}^{+}\right]=3.5-0.5 \log \left[\mathrm{Fe}^{+2}\right]
$$

Parkins ${ }^{5}$ showed that in nitrate solutions, the severity of cracking increases according to the cation series $\mathrm{Na}^{+}<\mathrm{Ca}{ }^{+}<\mathrm{NH}_{4}^{+}$. This series is also one of increasing acidity. This increase causes the open circuit potential of steels in these solutions to become successively more anodic. ${ }^{3}$ A consequence of the open circuit potential of the steel becoming more anodic is that at a corrosion site either the current density at the anode increases or cathodic reactions are accelerated. 
Corrosion, the precursor to cracking, is normally under the control of cathodic reactions in aqueous solutions ${ }^{6}$ and is relatively unaffected by minor changes in steel composition. The corrosion rate is influenced by the reduction kinetics and diffusion of reactants to cathodic sites. Nitrate is more easily reduced, as part of the cathodic reaction, as the solution becomes more acidic. In a variety of nitrate solutions, cracking is most rapid in the most acidic solutions because 1) they produce the largest anodic open circuit potential, and 2) cathodic reactions are stimulated more. As a result, corrosion is accelerated, and micropits or intergranular trenches form faster. Thus, cracking from local tensile stresses is initiated at the anodic portions of corrosion-produced defects.

On the basis of electrochemical theory, the best approach to reduce cracking would be to inhibit the cathodic reaction This reaction could be inhibited by increasing the concentrations of either the $\mathrm{NO}_{2}^{-}$or $\mathrm{OH}^{-}$or preferably both, as seen in Equation 2 .

An accepted theory of crack initiation in mild steel by nitrate solutions involves carbon in the stee1. ${ }^{7}$ Carbon can be present in solid solution or as $\mathrm{Fe}_{3} \mathrm{C}$ in the grain boundaries; it acts as an efficient cathode with the adjacent metal surface forming the anode of the electrochemical cell. This arrangement enhances anodic dissolution very close to the cathode leading to a micropit or trench, the precursor of a crack.

Anodic dissolution of the grain boundaries can be stimulated by impressing an electrical potential and causing a positive current to flow through a test sample. Current flows (and, therefore, the rate of dissolution of the metal) that can be developed for a given potential are defined by anodic polarization curves. Polarization studies show that in certain solutions where the metal shows an active-passive transition, such as mild steel in some SRP wastes, relatively large increases in current flows can be caused by a small increase in potential. Such potential differences may be caused by precipitates, second phases, or elements in solid solution, such as the carbon described above. These localized potential differences result in the localized attack required to initiate stress corrosion cracking. On the basis of these considerations, a tensile test apparatus was devised in which the sample could be strained to failure in a desired test solution while corroding under electrochemical control. Thus, the corrosion effects would be forced to occur, and the stress at corrosion-produced defects would be maximized because the sample is strained continuously. This type of arrangement would be expected, therefore, to provide the maximum differentiation in the effects of solution variables on the mechanical behavior of the specimen. 


\section{Experimental Method}

The test equipment is depicted in Figure 1. The threaded portion of the specimen screws into the grips of the tensile test machine. Surrounding the specimen is a platinum counter-electrode (cathode) which has one lead connected to a potentiostat. The cell is connected to a standard calomel reference electrode by a Teflon*-covered string salt bridge which enters the top of the cell and is positioned within $2 \mathrm{~mm}$ of the specimen. The other end of the bridge is immersed in a beaker containing test solution and the reference electrode at room temperature. The reference electrode lead is the second connection to the potentiostat and the lead from the threaded portion of the specimen is the third. An environmental chamber controls the temperature of the test specimen, cell, and solution within $\pm 1^{\circ} \mathrm{C}$. Change in solution concentration by evaporation during testing is prevented by a reflux condenser connected to the cell.

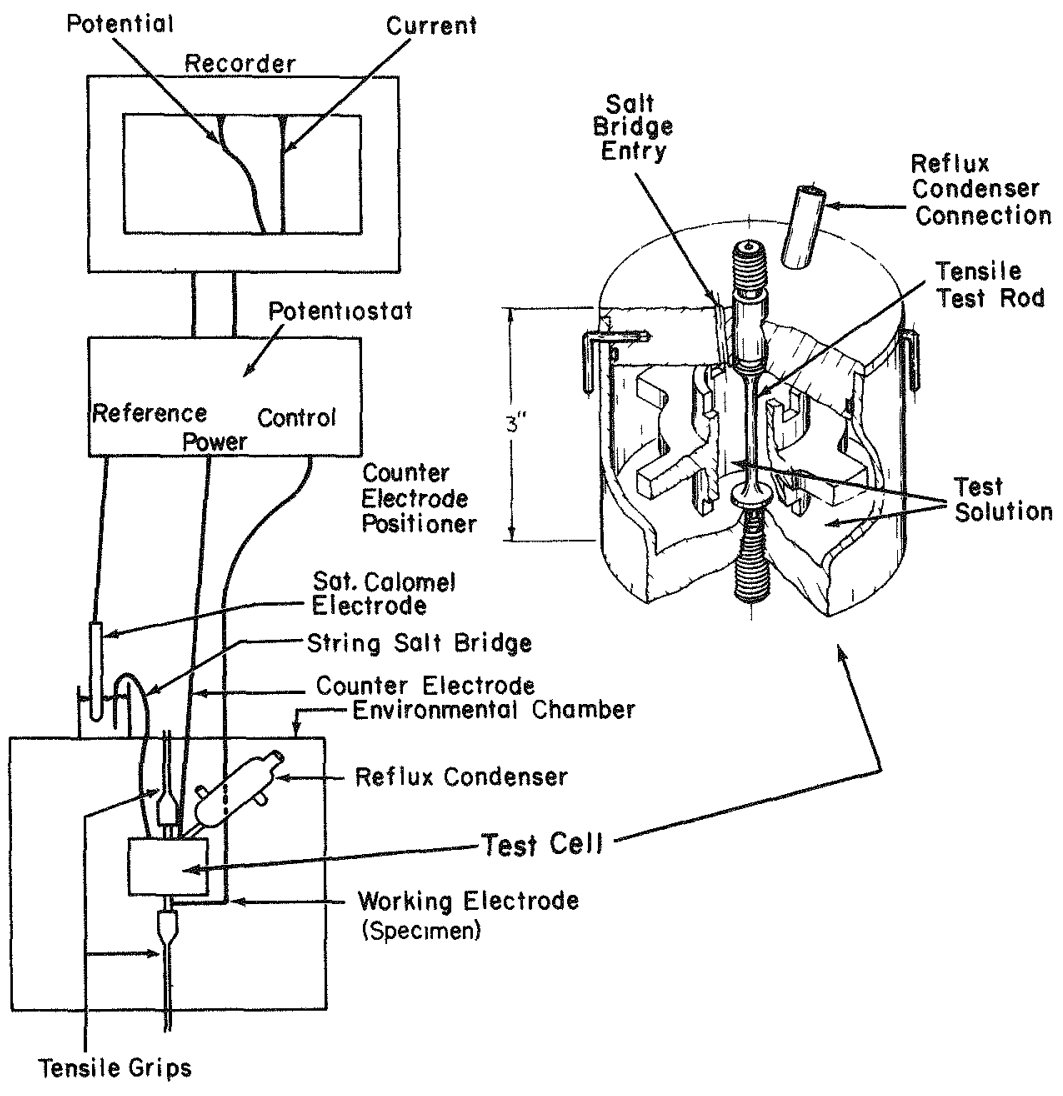

FIGURE 1. Electrochemical Tensile Test Equipment

*Trademark of E. I. du Pont de Nemours \& Company. 
The current flow between the counter electrode (platinum sheet) and working electrode (tensile specimen) is controlled by the potentiostat to within about $1 \%$ of the desired valve. Values of either $0.2 \mathrm{~mA} / \mathrm{cm}^{2}$ or $0.5 \mathrm{~mA} / \mathrm{cm}^{2}$ were selected because they represent the range of currents that would be obtained if a $0.01-\mathrm{V}$ local potential difference existed above the open-circuit potential based on polarization curves for the steel in several actual waste supernates. To attain the desired currents, the potentiostat imposes an equal but opposite potential on the counter electrode to produce the desired current flow and polarity on the specimen.

\section{WASTE COMPOSITIONS}

Typical compositional ranges for HHW and possible effects of the components on nitrate stress corrosion of mild steel are shown in Table 1.

Synthetic waste solutions were prepared as shown in Table 2 to correspond to analyses ${ }^{2}$ of samples taken either from the waste stored in the tank farm or from fresh waste in the process buildings. Solutions were chosen for wastes in both $\mathrm{F}$ and $\mathrm{H}$ Areas that would be expected to simulate extremes in aggressiveness (Tanks 1F, 8F, 9H, and 14H). The 221-F sample should be typical of fresh wastes currently generated by the Purex process and the 221-H sample should be typical of waste generated by the HM Process. Several special solutions were also made up (H Purex, $11 \mathrm{H}-13 \mathrm{H}$, and $32 \mathrm{H})$.

TABLE 1

Effects of High-Heat Waste Constituents on Steel Corrosion

\begin{tabular}{|c|c|c|c|}
\hline Ion & $\begin{array}{l}\text { Concer } \\
\text { Range, }\end{array}$ & ntration & Possible Effect \\
\hline $\mathrm{NO}_{3}^{-}$ & 1.6 & -4.5 & Cracking \\
\hline $\mathrm{NO}_{2}^{-}$ & 0.0 & -3.0 & $\begin{array}{c}\text { Inhibition (Pitting in very dilute } \\
\text { solutions) }\end{array}$ \\
\hline $\mathrm{OH}^{-}$ & 0.0 & -5.0 & Inhibition \\
\hline $\mathrm{Al}(\mathrm{OH})_{4}^{-}$ & 0.4 & -1.6 & Inhibition $\left(\mathrm{OH}^{-}\right.$required $)$ \\
\hline $\mathrm{CO}_{3}^{2-}$ & $<0.1$ & -0.3 & Inhibition \\
\hline $\mathrm{SO}_{4}^{2-}$ & 0.02 & -0.20 & Pitting \\
\hline $\mathrm{PO}_{4}^{3-}$ & 0.01 & -0.08 & Inhibition \\
\hline $\mathrm{Cl}^{-}$ & 0.005 & -0.11 & Pitting \\
\hline $\mathrm{CrO}_{4}^{2-}$ & 0.001 & -0.009 & Inhibition \\
\hline $\mathrm{F}^{-}$ & 0.001 & -0.004 & Pitting \\
\hline
\end{tabular}


TABLE 2

Plant Synthetic Test Solutions Based on Analyses

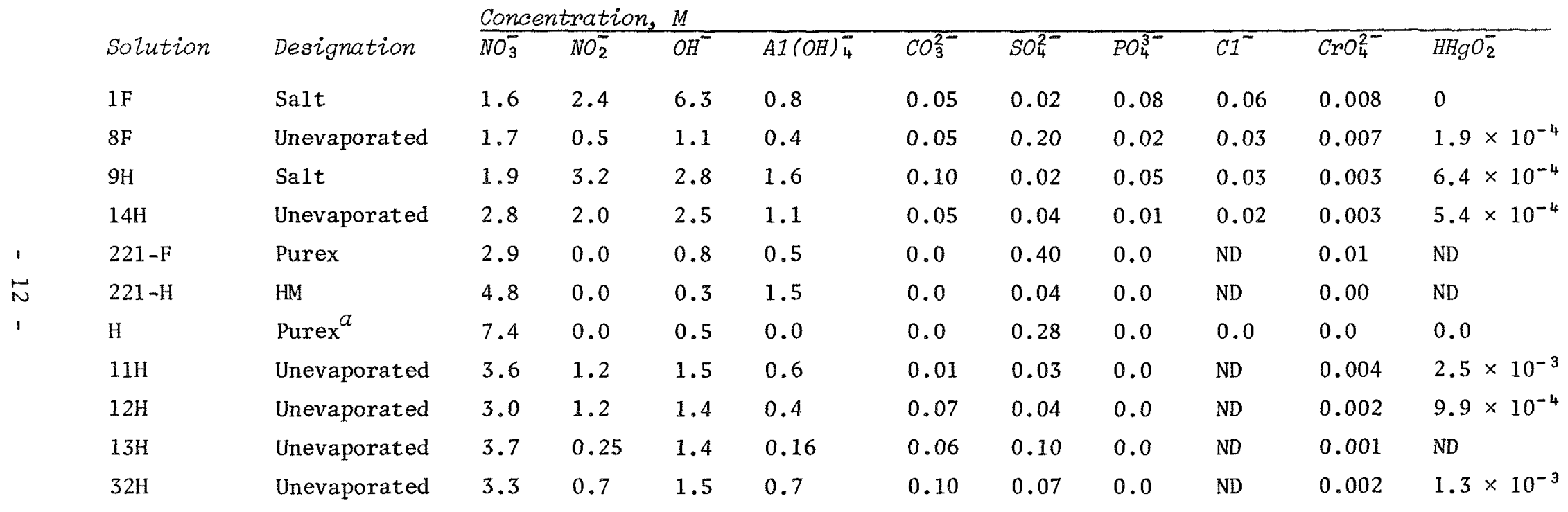

a. A hypothetical composition calculated from the process flow sheet. ${ }^{8}$ on chemical analyses of actual solutions, see Reference 2 .

A11 other compositions based ND - Not Determined. 


\section{MATERIALS}

Both A 285-B steel, the material of construction for Tanks $1-8,9-16 \mathrm{H}$, and A 516-70 steel, the material of construction for Tanks 29 to 34, were tested. The microstructures of these hot rolled steels are shown in Figure 2. The much coarser structure and larger amount of ferrite in A 285-B steel compared to A 516-70 steel are readily apparent. The composition of the steels and the ASTM specifications for these alloys are shown in Table 3.

\section{EXPERIMENTAL RESULTS}

The response of the two steels (Table 3 ) in the electrochemical tensile test in the various synthetic solutions relative to the properties measured in air are shown in Table 4.

Results in Table 4 show that A $516-70$ steel is generally superior to $A 285-B$ steel in resisting degradation in the test solutions. The strength of A 516-70 steel was not affected by any of the solutions, and the decrease in ductility is much less than for A 285-B. The data also show that even if no change occurs in strength, ductility values may decrease by as much as one-third.

The appearances of the tensile specimens of A 285-B steel, arranged in order of decreasing ductilities from left to right, are shown in Figure 3 . The highest ductility was shown by samples tested in air and solution 1F. The sample in solution $9 \mathrm{H}$ was intermediate. Samples tested in solutions $8 \mathrm{~F}$ and $14 \mathrm{H}$, which represent new waste directly from the process buildings, showed the least ductility. Samples tested in solutions $8 \mathrm{~F}$ and $14 \mathrm{H}$ had some small cracks along the gage length. Metallographic examination of these cracks (Figure 4) showed them to be typical of nitrate cracking, intergranular with the appearance of loose grains and corrosion product in the crack.

The test data plotted in Figure 5 also show correlation between ultimate tensile strength (UTS) and hydroxide concentration, as might be expected from Equation 2, if the corrosion reaction were under cathodic control. These data indicate that attack of A 285-B steel by $\mathrm{H}$ Area wastes aged about one year (Tanks 11-13 and $32 \mathrm{H}$ ) would have no more effect on strength than fresh $221-\mathrm{F}$ Purex waste. Fresh $221-\mathrm{H}$ waste proved to be the most aggressive solution encountered in plant operations. Furthermore, an acidified $8 \mathrm{M} \mathrm{NaNO}_{3}$ solution degraded the ultimate strength to about the level of the normal yield strength and produced a fracture with essentially no plastic deformation. Such a solution is strongly aggressive in producing stress corrosion in mild steels. 5 


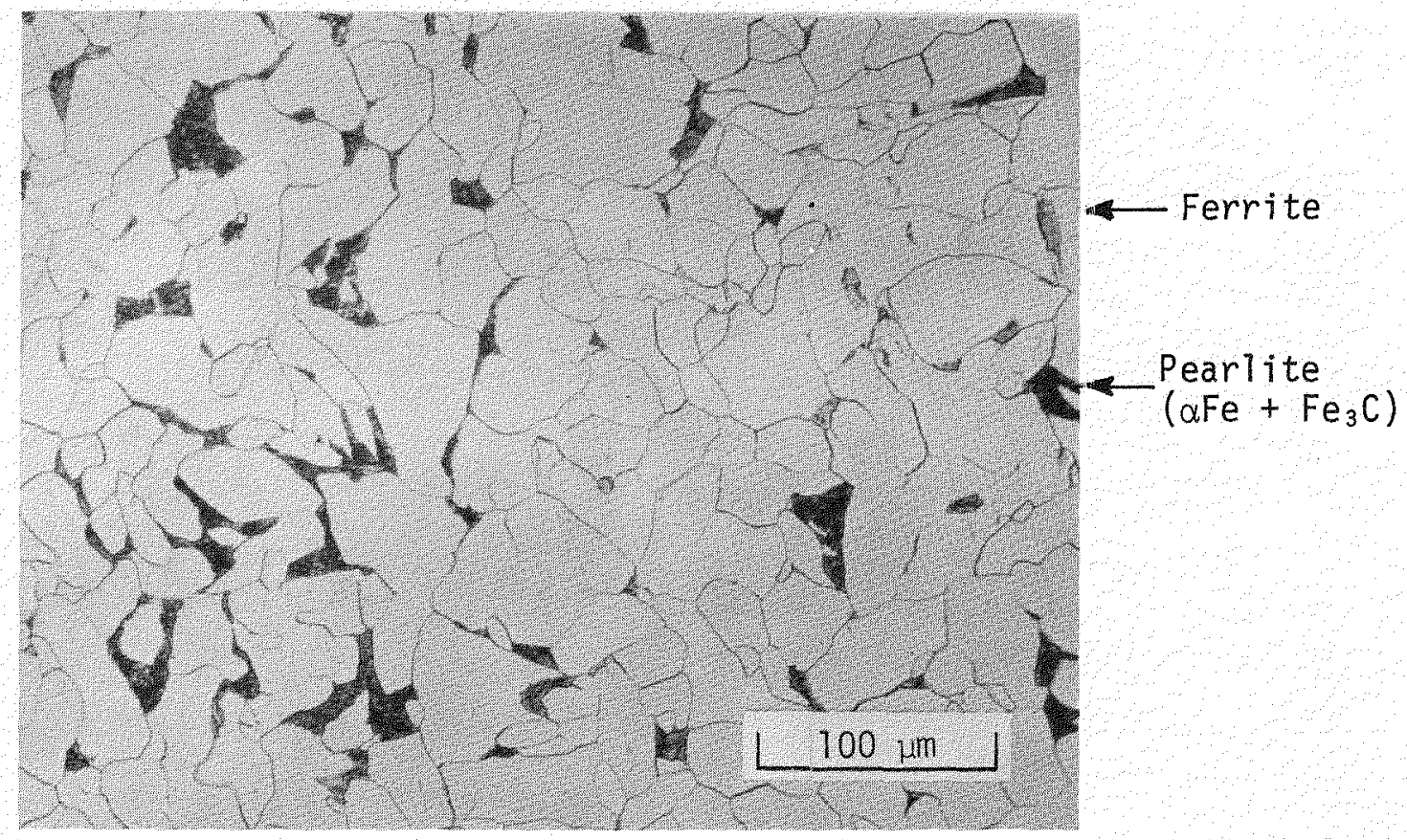

A $285-B$

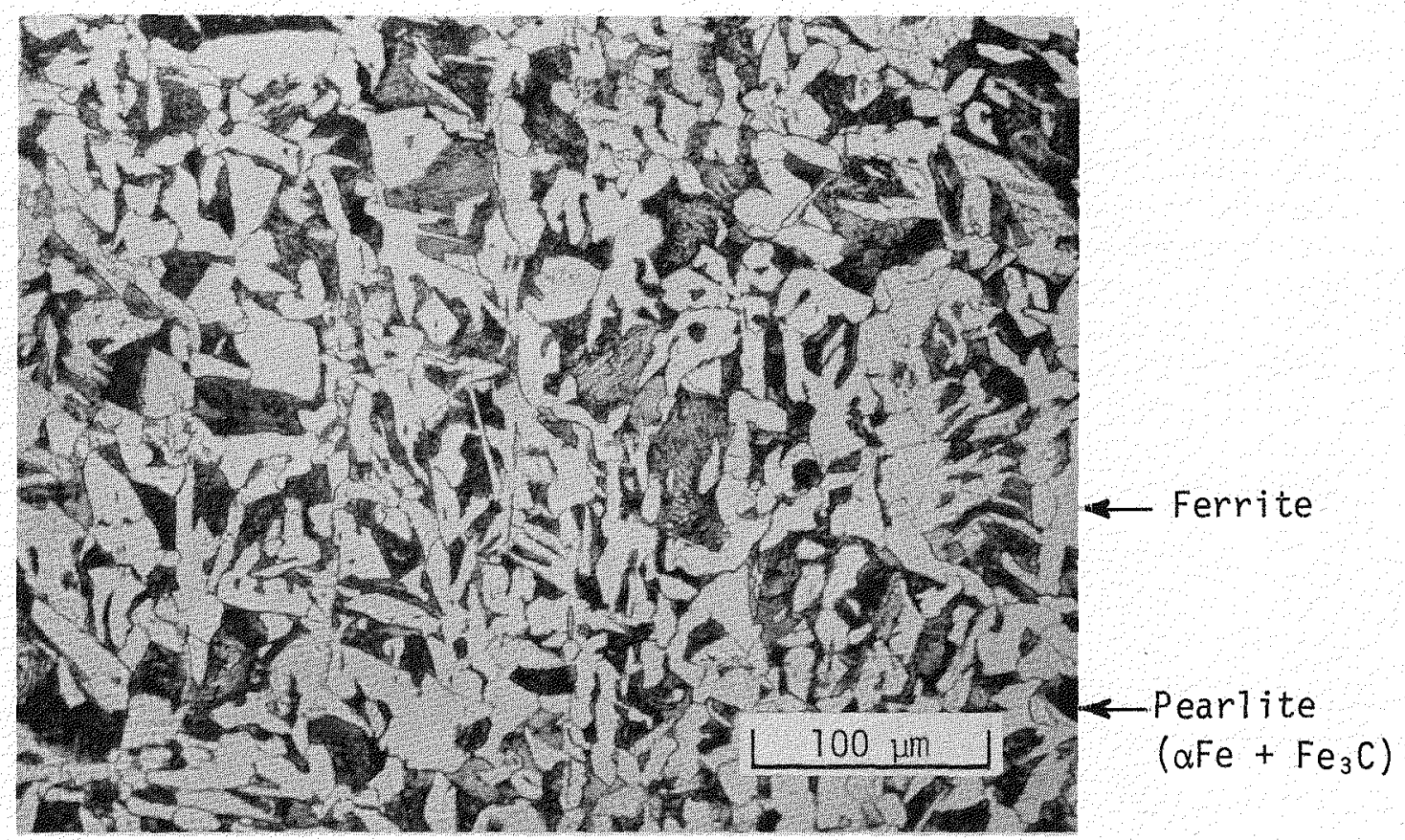

A $516-70$

FIGURE 2. Longitudinal Microstructure of A 285-B and A 516-70 Carbon Steels 
TABLE 3

Compositions of Test Alloys

\begin{tabular}{|c|c|c|c|c|c|c|c|}
\hline \multirow[b]{2}{*}{$A 285-B$} & \multicolumn{5}{|l|}{ Wt \% } & \multirow{2}{*}{$\begin{array}{l}\text { UTS } \\
\text { kpsi }\end{array}$} & \multirow{2}{*}{$\begin{array}{l}\text { Elongation, } \\
\text { (\%) }\end{array}$} \\
\hline & $\overline{M n}$ & Si & $C$ & $P$ & $\bar{S}$ & & \\
\hline Actual & 0.49 & - & 0.12 & 0.010 & 0.015 & 55.4 & 31 \\
\hline ASTM Specification & $0.90^{\alpha}$ & - & $0.22^{a}$ & $0.035^{a}$ & $0.045^{a}$ & $50-60$ & $25^{b}$ \\
\hline \multicolumn{8}{|l|}{ A $516-70$} \\
\hline Actual & 1.08 & 0.24 & 0.19 & 0.016 & 0.022 & 73.3 & 21 \\
\hline ASTM Specification & $0.80-1.25$ & $0.13-0.33$ & $0.28^{a}$ & $0.035^{a}$ & $0.040^{a}$ & $70-85$ & $17^{b}$ \\
\hline
\end{tabular}

a. Maximum.

b. Minimum.

TABLE 4

Tensile Properties in Electrochemical Tensile Test at $100^{\circ} \mathrm{C}$ and $0.5 \mathrm{~mA} / \mathrm{cm}^{2}$

\begin{tabular}{|c|c|c|c|c|}
\hline & & $\begin{array}{l}\text { Value in } \\
\text { to value }\end{array}$ & $\begin{array}{l}\text { Zution Indic } \\
\text { Air, \% }\end{array}$ & ed Relative \\
\hline A.zZoy & Solution ${ }^{a}$ & $\begin{array}{l}\text { Ultimate } \\
\text { Strength }\end{array}$ & Elongation & $\begin{array}{l}\text { Reduction } \\
\text { in Area }\end{array}$ \\
\hline A $285-B$ & $1 \mathrm{~F}$ & 100 & 100 & 95 \\
\hline & $9 \mathrm{H}$ & 100 & 72 & 36 \\
\hline & $8 \mathrm{~F}$ & 96 & 50 & 33 \\
\hline & $14 \mathrm{H}$ & 87 & 38 & 21 \\
\hline A $516-70$ & $1 \mathrm{~F}$ & 100 & 87 & 88 \\
\hline & $9 \mathrm{H}$ & 100 & 73 & 71 \\
\hline & $8 \mathrm{~F}$ & 100 & 60 & 68 \\
\hline & $14 \mathrm{H}$ & 100 & 60 & 68 \\
\hline
\end{tabular}

a. See Table 2 for compositions. 


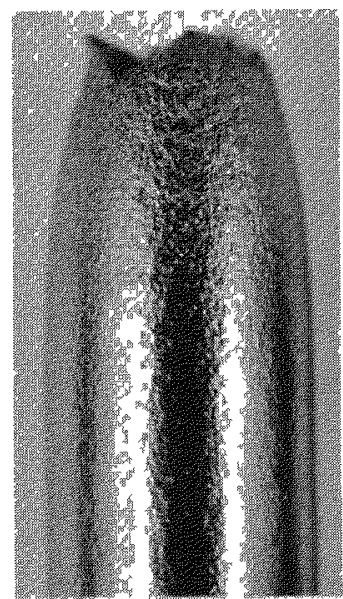

Air

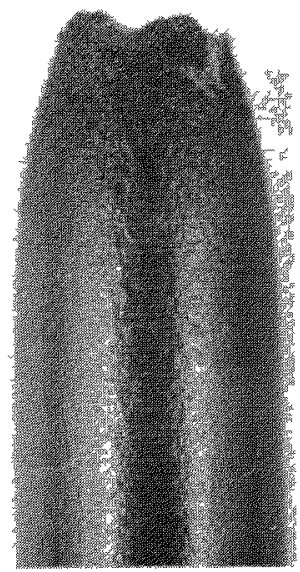

Tank IF Synthetic

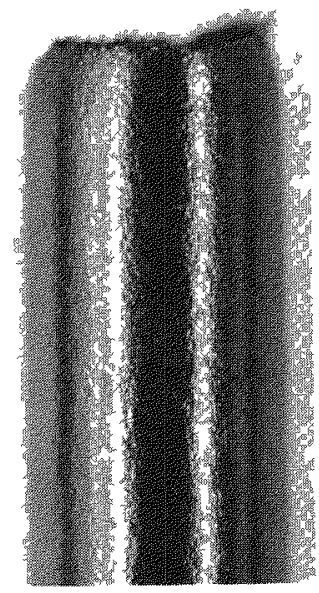

Tank 9H Synthetic

$4 \mathrm{~mm}$
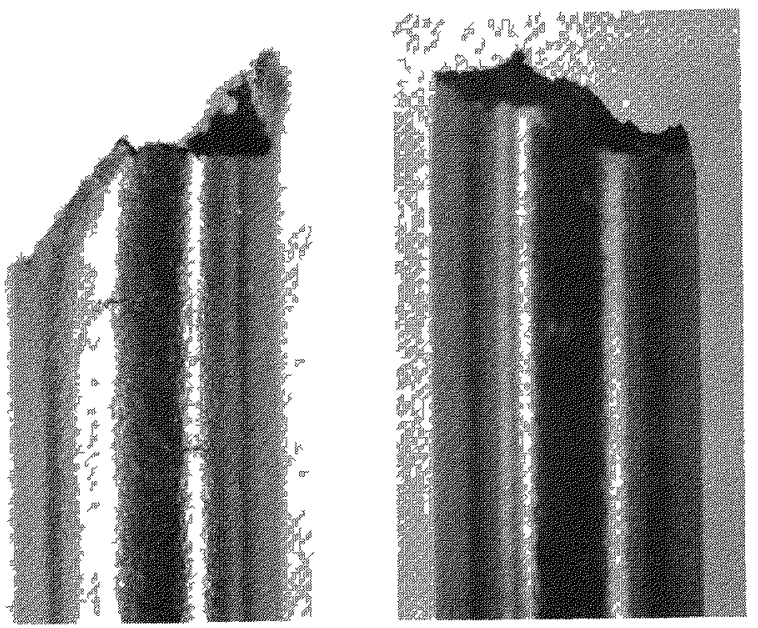

Tank 8F Synthetic Tank 14H Synthetic

FIGURE 3. Tensile Specimens of A 285-B Steel Tested in Various Media 


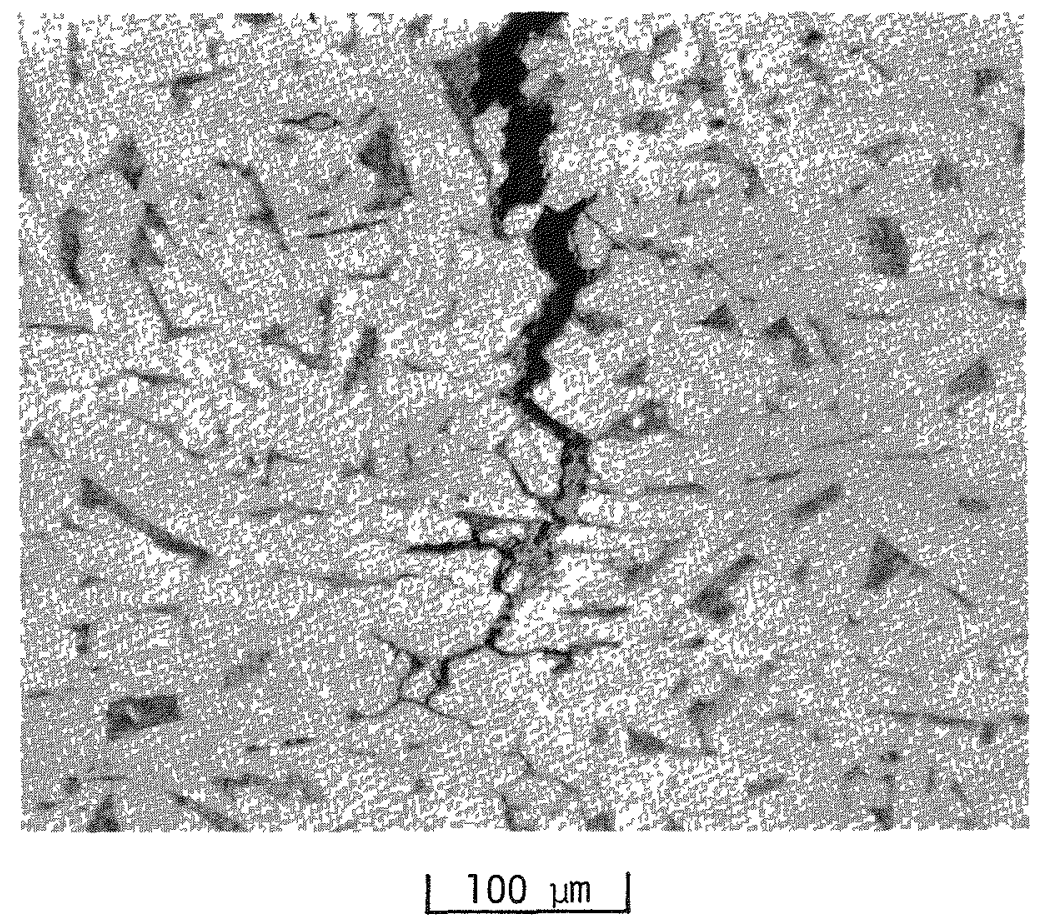

FIGURE 4. Intergranular Cracking of A 285-B Steel in Constant-Current Tensile Test

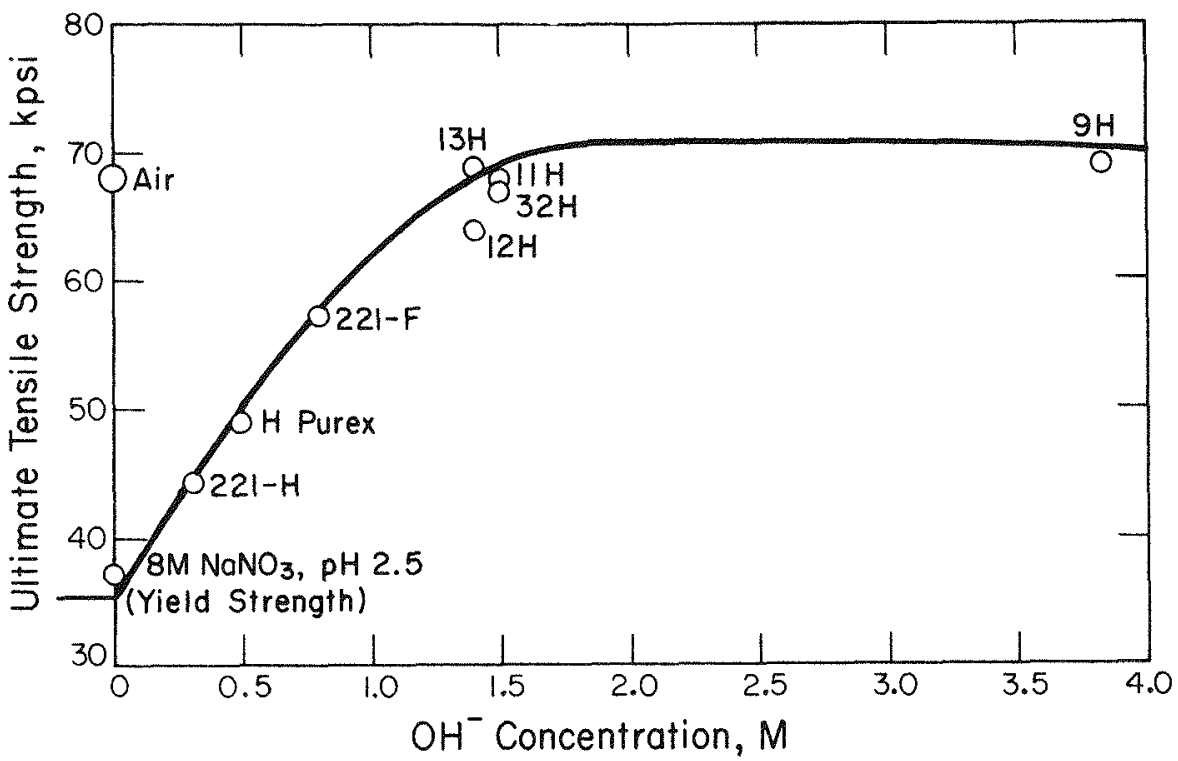

FIGURE 5. Electrochemical Tensile Test: Variation of Strength with Hydroxide Concentration of A $285-B$ Steel, $100^{\circ} \mathrm{C}, 0.2 \mathrm{~mA} / \mathrm{cm}^{2}$ 
Fractographs showed that specimens sustained greatest damage when the nitrate solutions contained the lowest concentrations of $\mathrm{NO}_{2}^{-}$and $\mathrm{OH}^{-}$. Figure 6 shows that the sample in 221-F Purex waste solution cracked along the gage length and failed with almost no reduction in area (total $\mathrm{NO}_{2}^{-}$and $\mathrm{OH}^{-}$was $0.8 \mathrm{M}$ ). The other two samples (with total $\mathrm{NO}_{2}^{-}$and $\mathrm{OH}^{-} \geq 1.6 \mathrm{M}$ ) did not crack and showed more ductility with a shear fracture profile. The fracture surfaces were severely corroded; the sample tested in 221-F Purex waste also showed frequent intergranular separations, and a fracture surface more characteristic of brittle rupture. The other two samples showed dimples resulting from microvoid formation that is typically found in the fracture of a very ductile material.

The tensile tests discussed in the previous paragraphs were made at $100^{\circ} \mathrm{C}$. Less degradation in tensile properties was observed at lower temperatures because of decreased corrosion rates. This is shown for A $285-\mathrm{B}$ steel in $221-\mathrm{H}$ waste, an aggressive solution, at three different temperatures in Table 5 .

Table 5

Relative Tensile Properties of A 285-B Steel in $221-\mathrm{H}$ Waste at $0.2 \mathrm{~mA} / \mathrm{cm}^{2}$

\begin{tabular}{llll} 
Temperature, & \multicolumn{3}{c}{ Fraction of Values in Air, \% } \\
\hline${ }^{\circ} \mathrm{C}$ & $\begin{array}{l}\text { Utimate } \\
\text { Strength }\end{array}$ & Elongation & $\begin{array}{l}\text { Reduction } \\
\text { In Area }\end{array}$ \\
50 & 100 & 100 & 100 \\
75 & 95 & 50 & 70 \\
100 & 65 & 30 & 20
\end{tabular}

The data (Table 5) indicate that wastes as aggressive as $221-\mathrm{H}$ waste should be stored at $<75^{\circ} \mathrm{C}$ (preferably $<50^{\circ} \mathrm{C}$ ) if the tensile properties are an important factor in nitrate cracking. 
$221-\mathrm{F}$

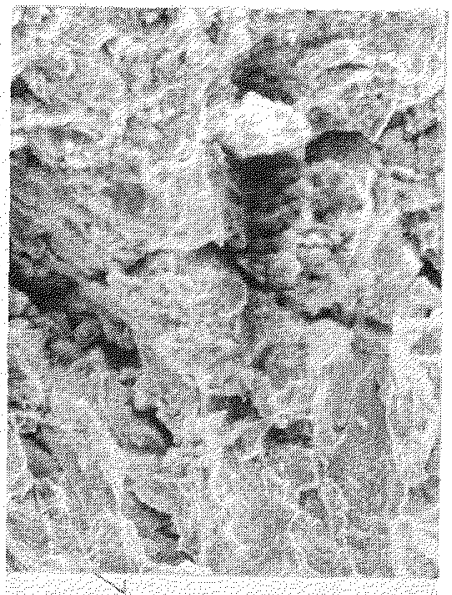

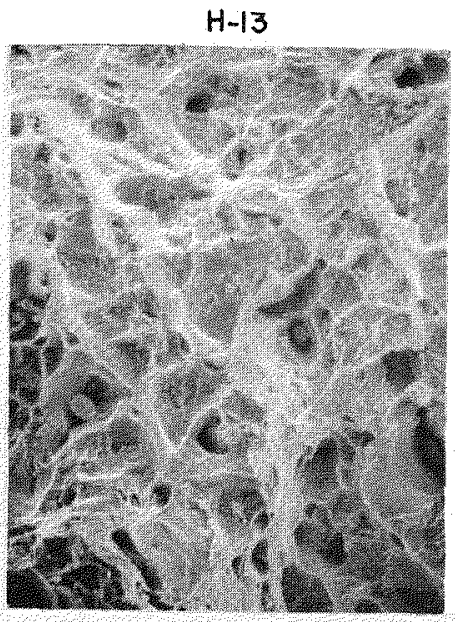
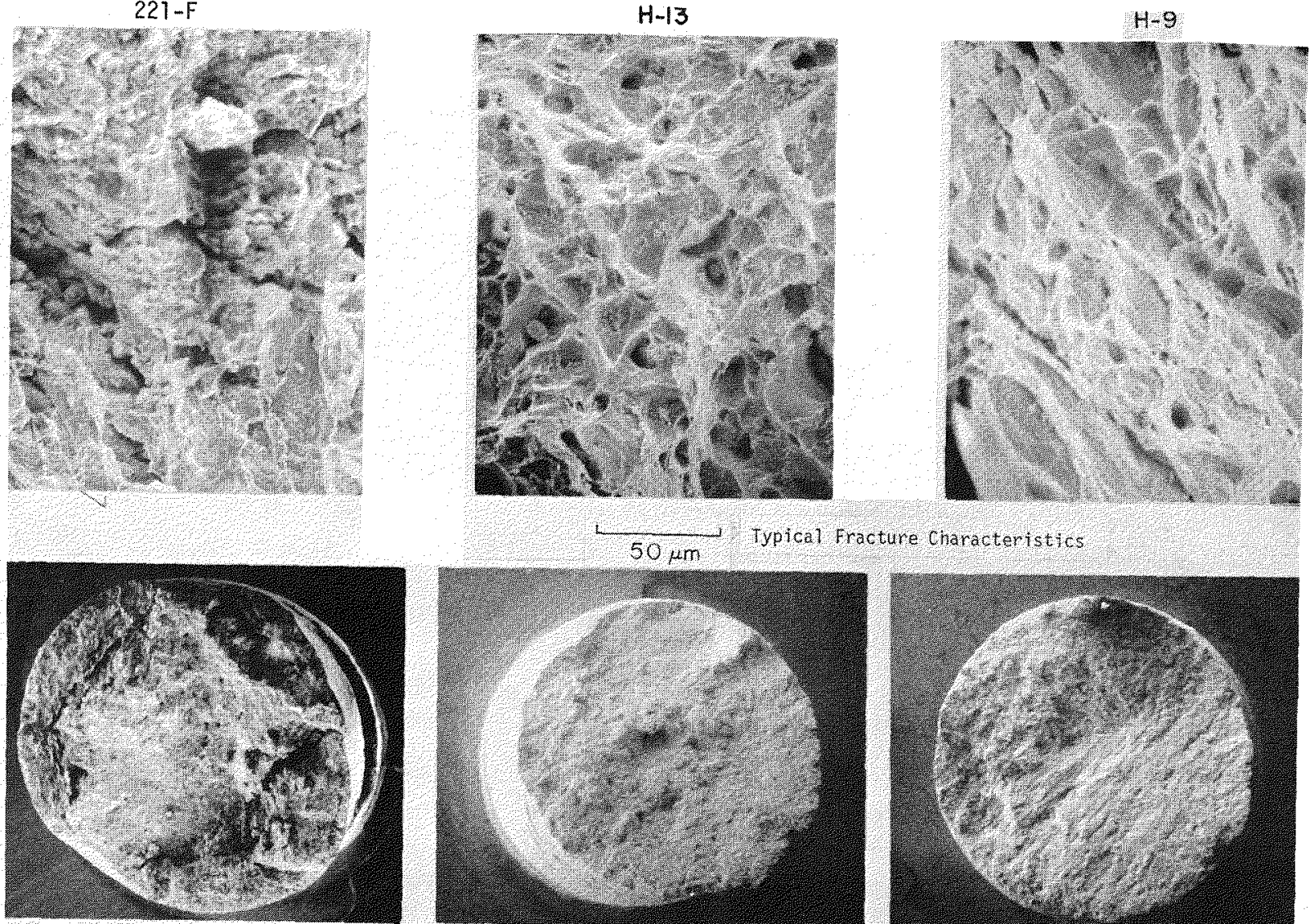

50 um Typical frocture Ciraracteristics
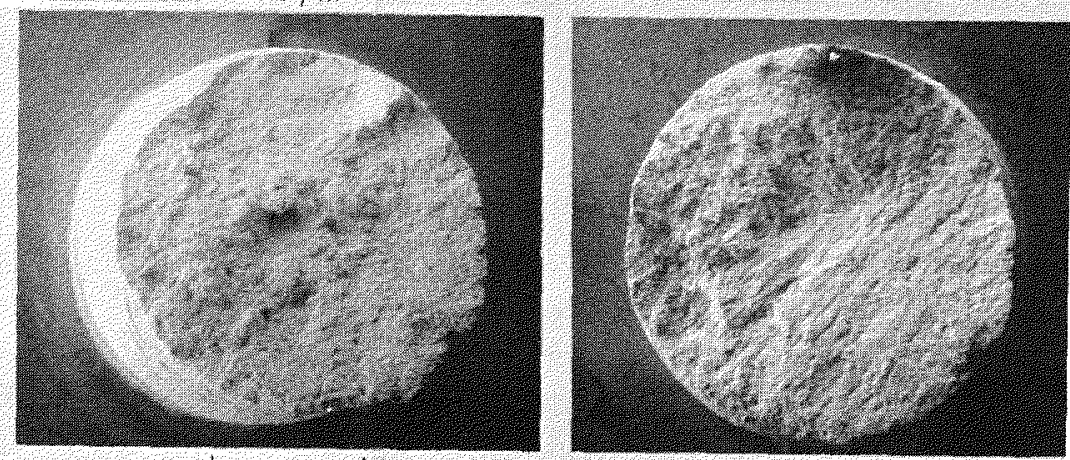

$1 \mathrm{~mm}+$ nalf of fracture Surface
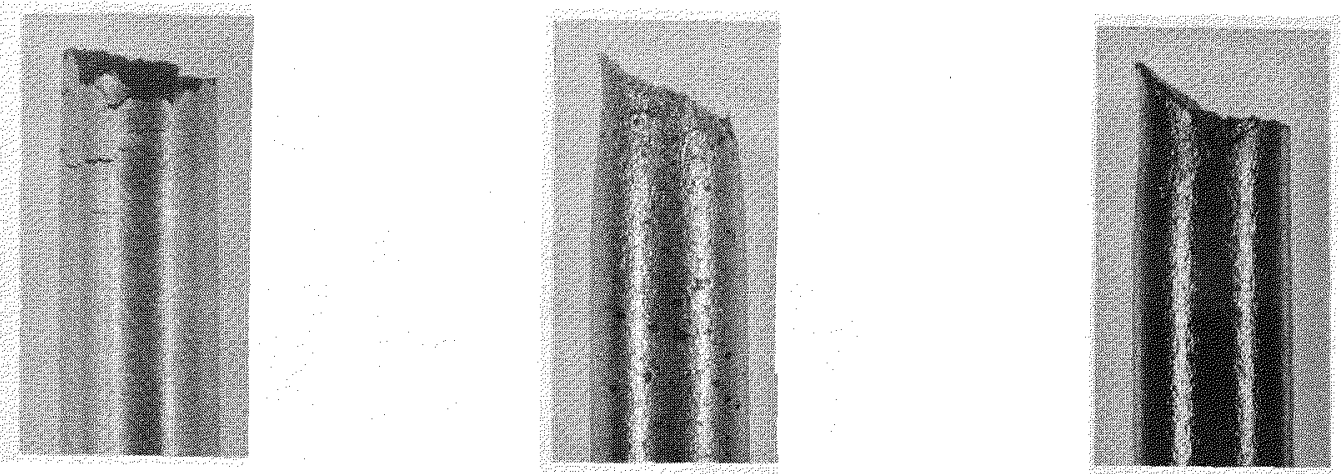

portion of Gade length at Fracture locetton

$4 \mathrm{~mm}$

FIGURE 6. Fracture Characteristics of A $285-B$ Steel in $0.2 \mathrm{~mA} / \mathrm{cm}^{2}$ Tensile Test 


\section{STATISTICAL EVALUATION OF EFFECTS OF VARIABLES}

Results with simulated wastes showed a pattern of aggressive attack that was consistent with Plant experience:

- Fresh waste at high temperature was most likely to produce stress corrosion-cracking.

- Fresh waste from $H$ Area was somewhat more aggressive than that from $F$ Area.

Except for $\mathrm{OH}^{-}$, however, direct correlations of attack with specific values of ionic concentrations could not be developed from the preliminary data. For this reason a detailed statistical evaluation of the effects of the variables was undertaken. Two experimental designs were followed: the Plackett-Burman, ${ }^{9}$ to identify the major variables; and the Box-Behnkin, 10 to evaluate the effects of these variables.

\section{Plackett-Burman Series}

A Plackett-Burman design ${ }^{9}$ was used to identify the major variables affecting stress corrosion cracking. This design is generally used for screening the variable space in selected portions of a $2^{n}$ factorial design where one variable is changed at a time with a high and low value for each independent variable. As a screening design, the Plackett-Burman design has the advantage that a relatively small number of experiments is required to investigate a large number of independent variables; it has the disadvantage of eliminating interaction effects, such as the effects of inhibitors, and presenting them as an inflation of experimental error.

Because many independent variables can affect cracking, the Plackett-Burman test series included seven independent variables, temperature and six anionic concentrations. This approach required only 12 experiments rather than 128 for a $2^{\text {n }}$ factorial with one high and one low value for each independent variable. The variables are shown in Table 6 .

Four dependent variables, ultimate tensile strength (UTS) and three measures of ductility, were chosen as properties that might be affected by the independent variables. These variables are shown in Figure 7 , a stylized stress-strain curve. The ultimate strength is the point on the curve where uniform elongation ends and necking begins. Total elongation at fracture and uniform elongation provide two measures of ductility; the reduction in cross sectional area that results during necking provides the third. 
TABLE 6

Plackett-Burman Variables and Constants

Independent Variables

\begin{tabular}{|c|c|c|c|c|c|}
\hline \multirow[b]{2}{*}{ Temp., ${ }^{\circ} \mathrm{C}$} & \multirow{2}{*}{$\begin{array}{l}\text { Low }^{a} \\
50\end{array}$} & \multirow{2}{*}{$\begin{array}{l}H i g h^{a} \\
100\end{array}$} & \multirow{2}{*}{$\begin{array}{l}\text { Dependent Variables } \\
\text { UTs }\end{array}$} & \multicolumn{2}{|c|}{ Constants $^{a, b}$} \\
\hline & & & & $\mathrm{CO}_{3}^{2-}$ & 0.1 \\
\hline $\mathrm{NO}_{3}^{-}$ & 1.5 & 5.5 & Total Elongation & $\mathrm{SO}_{4}^{2-}$ & 0.1 \\
\hline $\mathrm{NO}_{2}^{-}$ & 0 & 3.5 & Uniform Elongation & $\mathrm{PO}_{4}^{3-}$ & 0.05 \\
\hline $\mathrm{Al}(\mathrm{OH})_{4}^{-}$ & 0 & 1.6 & Reduction in Area & $\mathrm{CrO}_{4}^{2-}$ & 0.005 \\
\hline $\mathrm{OH}^{-}$ & 0 & 6.0 & & & \\
\hline $\mathrm{Cl}^{-}$ & 0.005 & 0.15 & & & \\
\hline $\mathrm{HHgO}_{2}^{-}$ & 0 & 0.002 & & & \\
\hline
\end{tabular}

a. All ionic values are $M$.

$b$. Added to simulate HHW.

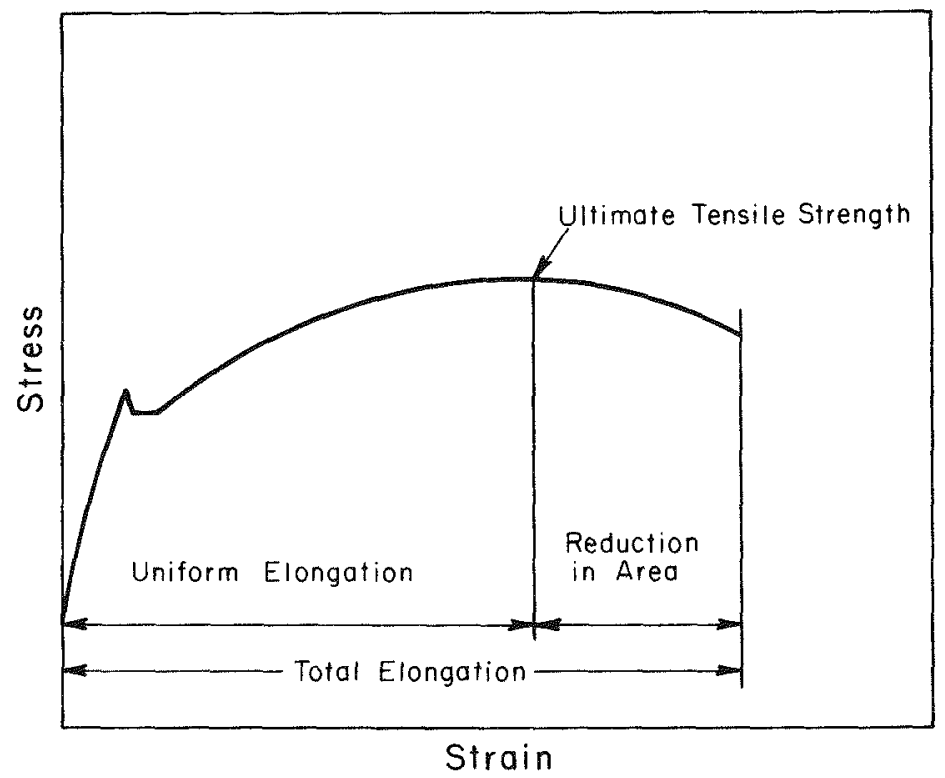

FIGURE 7. Stylized Stress-Strain Curve 
Analyses of the Plackett-Burman data showed that temperature and $\mathrm{NO}_{3}^{-}$concentration more strongly affected the measured ductility than either interactions and experimental error did. All three ductility variables were correlated at the $90 \%$ confidence level with the experimental variation in temperature and $\mathrm{NO}_{3}^{-}$concentration. In the case of UTS, however, ion interactions apparently caused inflation of experimental error, and no statistically significant correlation to the independent variables was found. From the previous results (Figure 5), the $\mathrm{OH}^{-}$concentration was believed to be an important interacting ion. Also, Equation 2 and electrochemical theory ${ }^{1,} \mathrm{I}_{2}$ would predict both $\mathrm{OH}^{-}$and $\mathrm{NO}_{2}^{-}$to be influential interacting ions. To evaluate the correlations between interacting ions and the independent variables, an additional statistically designed experiment was performed as described in the following section.

\section{Box-Behnkin Series}

\section{Conditions and Variables}

The simultaneous effects of temperature, nitrate, nitrite, and hydroxide on strength and ductility of A 285-B steel were systematically evaluated using a Box-Behnkin series of experiments.10 A four-dimensional computer analysis of these data combined with the plackett-Burman data resulted in two equations, one for ultimate tensile strength and one for elongation. These equations predict the strength or ductility for any combination of temperature and nitrate, nitrite, and hydroxide concentrations within the ranges of 50 to $100^{\circ} \mathrm{C}, 1.5$ to $5.5 \mathrm{M} \mathrm{NO}_{3}^{-}$, 0 to $3.5 \mathrm{M} \mathrm{NO}_{2}^{-}$, and 0 to $5.0 \mathrm{M} \mathrm{OH}^{-}$. The predictions can be printed out as contour maps, operating maps, or values for specific combinations of the four independent variables.

In the Box-Behnkin series, other constituents in the waste were held constant. One of these, aluminate, is a major constituent and is known to have a significant effect on caustic cracking, probably because of the hydroxide required to keep it in solution. However, aluminate apparently has at most a minor effect in nitrate cracking. Of the minor HHW constituents, $\mathrm{SO}_{4}^{2-}$ and $\mathrm{Cl}^{-}$are often corroding agents and, therefore, could initiate the stress corrosion cracking sequence. Mercury changes the open circuit potential of steel by 0.4 to $0.5 \mathrm{~V}$ in the positive direction and could put the steel in the potential range for nitrate cracking. The wastes also contain inhibitors, such as $\mathrm{CO}_{3}^{2-}, \mathrm{PO}_{4}^{3-}$, and $\mathrm{CrO}_{4}^{2-}$; some have high enough concentrations to inhibit steel corrosion in water. Therefore, these ions were included in the test solutions at a constant level which simulates the concentrations routinely found in HHW. 
A limited series of electrochemical tensile tests was selected on the basis of the Box-Behnkin statistical series. The usual method of varying each factor individually (factorial design) would have required prohibitively extensive testing as seen in Table 7. The conditions selected for the expeximental series are shown in Table 8 .

Tests at appropriate combinations of the low, mean, and high values of the independent variables were run. The combinations were assigned to each test according to the standard four-variable Box-Behnkin design, and the corresponding tensile tests were performed in random order.

For the data reduction, a multiple regression, least squares program was used with the following features: 1) a full quadratic mode1, 2) an augmented correlation matrix to show correlation among all independent and dependent variables, and 3) analyses of residuals to reject results with large errors. The program also could plot dependent variables against each other to test whether each dependent variable measured the same or different effects. other output data included equations representing the dependent variables and contour maps of the fitted dependent variables.

To improve the precision of the equations describing the response surfaces, especially in certain sections, the Box-Behnkin data (27 tests) were combined with the Plackett-Burman data (12 tests) and five additional experiments were completed. Only one result of the 44 was rejected on the basis of the computer analysis of residuals; the remaining were used to establish the equations for the response surface.

The resulting experimental design was quite good; the efficiency was $30 \%$ (predictions are $30 \%$ as precise as the most precise experimental design possible). An actual experimental series cannot usually be designed to exceed $50 \%$ efficiency and nonstatistical experimental series with 1 to $5 \%$ efficiency are common.

TABLE 7

Factorial and Box-Behnkin Designs

\begin{tabular}{lll} 
Independent & \multicolumn{2}{l}{ Number of Expeximents } \\
\cline { 2 - 2 } Three-Level & Box-Behninin \\
Factorial & Design \\
3 & 27 & 15 \\
4 & 81 & 27 \\
5 & 243 & 46
\end{tabular}


TABLE 8

Box-Behnkin Conditions

$\frac{\text { Independent Variables }}{\text { Range }}$

Dependent Variables Constants, ${ }^{a} M$

Temp., ${ }^{\circ} \mathrm{C} \quad 50-100 \quad$ UTS

$\mathrm{NO}_{3}^{-}, \mathrm{M} \quad 1.5-5.5 \quad$ Total Elongation

$\mathrm{A} 1(\mathrm{OH})_{4}^{-} \quad$ Sat. $0-1.5$

$\mathrm{NO}_{2}^{-}, \mathrm{M} \quad 0-3.5$

Uniform Elongation

$\mathrm{CO}_{3}^{2-}$

0.1

$\mathrm{OH}^{-}, \mathrm{M}$

$0-5.0$

Reduction in Area

$\mathrm{SO}_{4}^{2-}$

0.1

$\mathrm{PO}_{4}^{3-}$

0.05

$\mathrm{CrO}_{4}^{2-}$

0.005

$\mathrm{HHgO}_{2}^{-}$

0.002

a. Added to simulate HHW.

Cross plots of the four dependent variables showed that only two responses were present, one for UTS and one for ductility (total elongation, uniform elongation or reduction in area). The first equation relates UTS to changes in $\mathrm{NO}_{3}^{-}$and $\mathrm{OH}^{-}$concentration. The second equation for ductility was similar to the first, but more complex. Ductility correlated with temperature, nitrate, nitrite, and hydroxide; with the nitrate effect depended on temperature as well as on nitrite concentration.

\section{Ductility Equation and Contour Maps}

The ductility response was chosen as the more important because stress corrosion is a phenomenon in which normally ductile material behaves in a brittle (less ductile) manner. An equation was developed specifically for total elongation because this is the simplest ductility property to measure in a tensile test. The equation, a Taylor Series shown here, is long (33 coefficients), but relatively simple in that it only has linear, cross-product and quadratic terms of the four independent variables.

$$
\begin{aligned}
\% \text { Elongation }= & 9.96-0.0077 a+0.330 b-0.086 c+0.038 d \\
& +0.010 a^{2}-0.062 b^{2}+1.07 c^{2}+1.16 d^{2} \\
& +0.0009 a b+0.037 a b^{2}-0.0007 a^{2} b+0.0002 a^{2} b^{2} \\
& +0.017 a c-0.019 a c^{2}-0.0013 a^{2} c-0.0020 a^{2} c^{2} \\
& +0.0098 a d-0.0022 a d^{2}-0.00009 a^{2} d-0.015 a^{2} d^{2} \\
& +0.173 b c-0.126 b c^{2}+0.149 b^{2} c+0.295 b^{2} c^{2} \\
& +0.086 b d-0.039 b d^{2}+0.079 b^{2} d+0.033 b^{2} d^{2} \\
& -0.44 c d+0.101 c d^{2}-0.0055 c^{2} d-0.202 c^{2} d^{2}
\end{aligned}
$$


where

$$
\begin{aligned}
& \mathrm{a}=\operatorname{Temp}\left({ }^{\circ} \mathrm{C}\right)-75 \\
& \mathrm{~b}=\left[\mathrm{NO}_{3}^{-}\right]-3.5 \\
& \mathrm{c}=\left[\mathrm{NO}_{2}^{-}\right]-1.75 \\
& \mathrm{~d}=\left[\mathrm{OH}^{-}\right]-2.5
\end{aligned}
$$

One way to use Equation 5 is to generate families of curves representative of concentrations or temperatures of interest. One such family is illustrated in Figure 8, in which conditions are similar to those that might be expected for fresh $\mathrm{HHW}$; temperature is high, $100^{\circ} \mathrm{C}$, and nitrite is 10w. Analyses have shown the presence $<0.05 \mathrm{M}$ nitrite in Purex and HM wastes directly from the 221 Buildings. Elongation is plotted against hydroxide concentration for several concentrations of nitrate. The line at $13 \%$ elongation separates samples that always cracked during the test from samples that generally did not show surface cracking. (See also the discussion below.)

Elongations calculated from Equation 5 can also be illustrated as a contour map. Any two of the four independent variables are held constant on a given map with the other two variables plotted against each other. The contour lines separate selected ranges of the dependent variable. A series of maps may be printed with incremental changes in either of the two independent variables not plotted, and the contour lines gradually shift. Figure 9 shows one such map in which hydroxide is plotted against nitrate at constant temperature and nitrite concentration. The contours indicate conditions that produce constant elongations. Figure 10 gives a series of sections showing the shift with temperature of the contours delineating $13 \%$ elongation.

Genera1 contour maps are usually too complex for operation of a process. Normally operating limits are chosen, and printouts made that illustrate "operate-do not operate" areas on a series of maps. Typical maps are shown in Figures 11 and 12. Most fresh wastes fall in the lower left-hand corners of these maps.

The absence of any contours in the map for $50^{\circ} \mathrm{C}$, even at $0.0 \mathrm{M} \mathrm{NO}_{2}^{-}$indicates that below this temperature, wastes within the compositions tested should not initiate the stress corrosion sequence, as defined by the electrochemical tensile test.

The limit of $13 \%$ total elongation was selected as a figure of merit in these contour maps for three reasons. First, the samples from the Plackett-Burman and Box-Behnkin series were examined. At $13 \%$ or less total elongation, A $285-\mathrm{B}$ steel samples always showed surface cracks along the gage length. At greater elongations such cracking was unusual and always minor if observed. 
Second, evaluation of tensile test data in air showed that the limit of uniform elongation was about $13 \%$; this is the point of maximum load and the point at which stresses in a tensile specimen change from biaxial to triaxial. Triaxial stresses are generally considered to be more effective in crack initiation of polycrystalline materials. Finally, the $13 \%$ limit was consistent with results of tests using a fracture mechanics approach to evaluate crack growth. ${ }^{13}$ These tests used wedge-opening-loaded specimens at $97^{\circ} \mathrm{C}, 5.0 \mathrm{M} \mathrm{NO}_{3}^{-}$in the ranges of 0 to $1.5 \mathrm{M} \mathrm{NO}-\overline{2}$ and 0 to $1.5 \mathrm{M} \mathrm{OH}^{-}$.

A region in which the indicated elongation is less than $13 \%$ exists in the center of the variable space between about $57^{\circ}$ and $94^{\circ} \mathrm{C}$, as shown in Figure 13 . This region is an irregular volume centered at approximately $75^{\circ} \mathrm{C}, 2 \mathrm{M} \mathrm{NO}_{2}^{-}$and $2.5 \mathrm{M}^{\circ} \mathrm{H}^{-}$; the volume enclosed is maximum at about $3.5 \mathrm{M} \mathrm{NO}_{3}^{-}$. The low value of elongation in this region is largely influenced by the single point determined by triplicate tests that give a low elongation at $75^{\circ} \mathrm{C}$ and $3.5 \mathrm{M}$ $\mathrm{NO}_{3}^{-}, 1.7 \mathrm{M} \mathrm{NO}-$, and $2.5 \mathrm{M} \mathrm{OH}^{-}$. According to the statistical tests included in the Box-Behnkin analysis, this result was a valid test. (As indicated above, one other result among the 44 tests was excluded from the analysis based on these tests.)

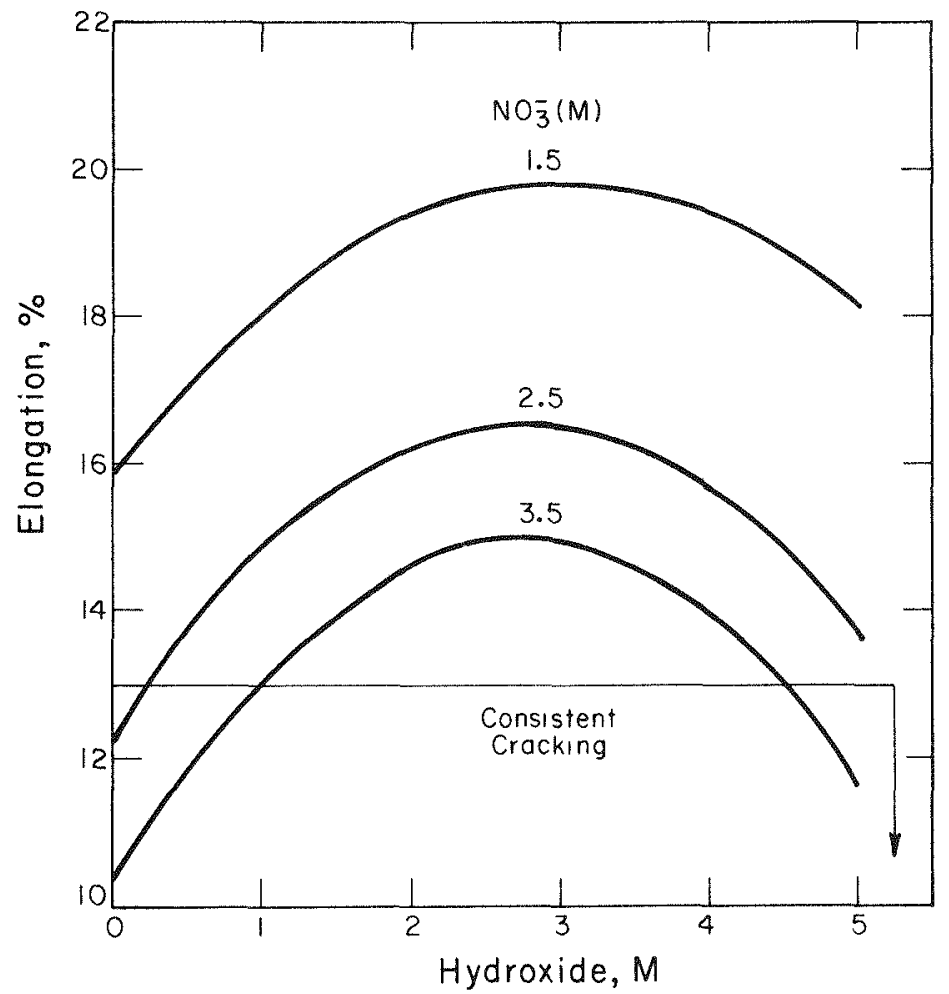

FIGURE 8. Elongation of A 285-B Mild Steel vs. Hydroxide Concentration in $\mathrm{HHW}, 100^{\circ} \mathrm{C}, 0.0 \mathrm{M} \mathrm{NO}$ 


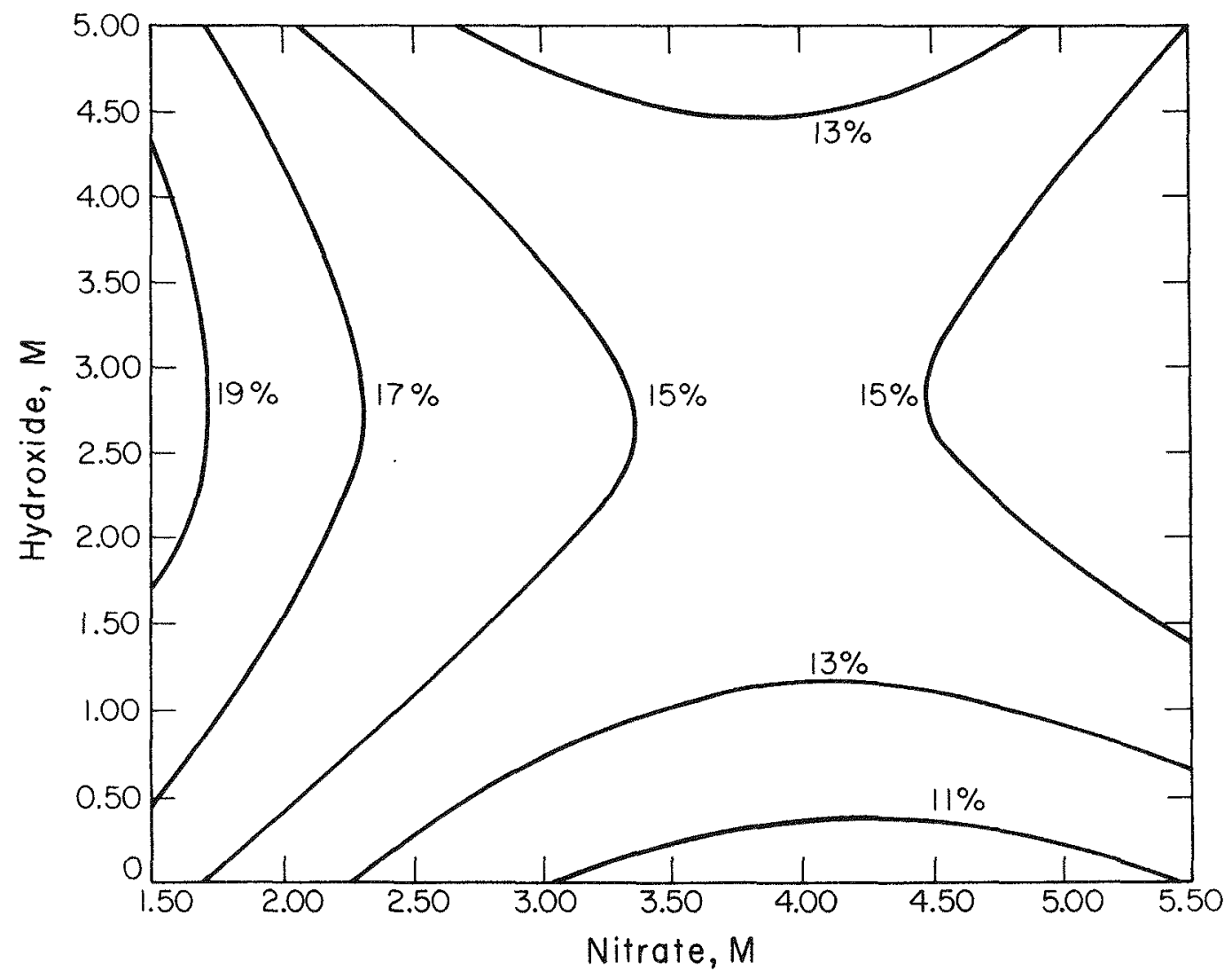

FIGURE 9. Contour Map of Elongation of A 285-B Steel in Electrochemical Tensile Test, $100^{\circ} \mathrm{C}, 0.0 \mathrm{M} \mathrm{NO}_{2}^{-}$ 

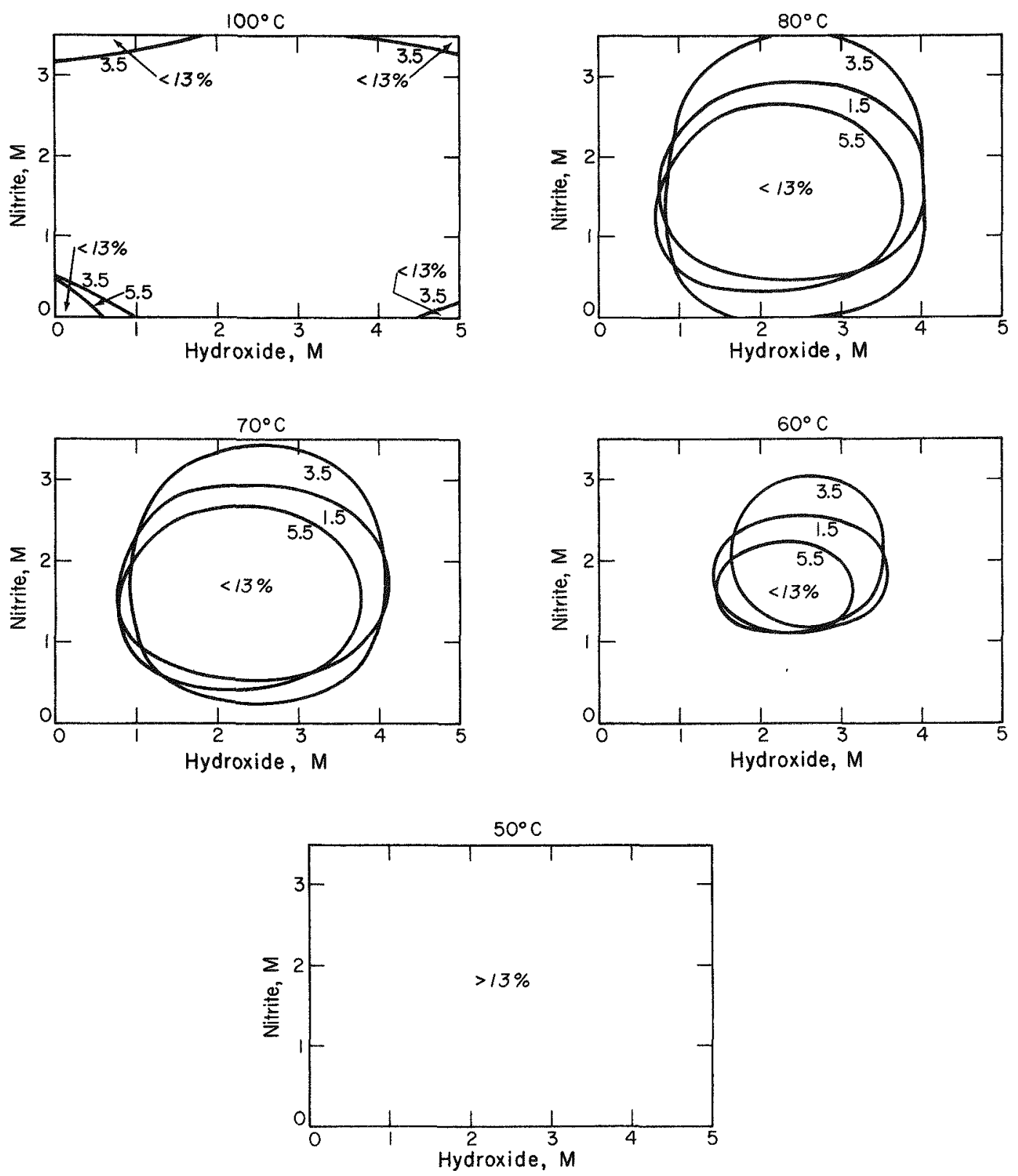

FIGURE 10 . Contours of $13 \%$ Elongation at Various Temperatures and Nitrate Concentrations 


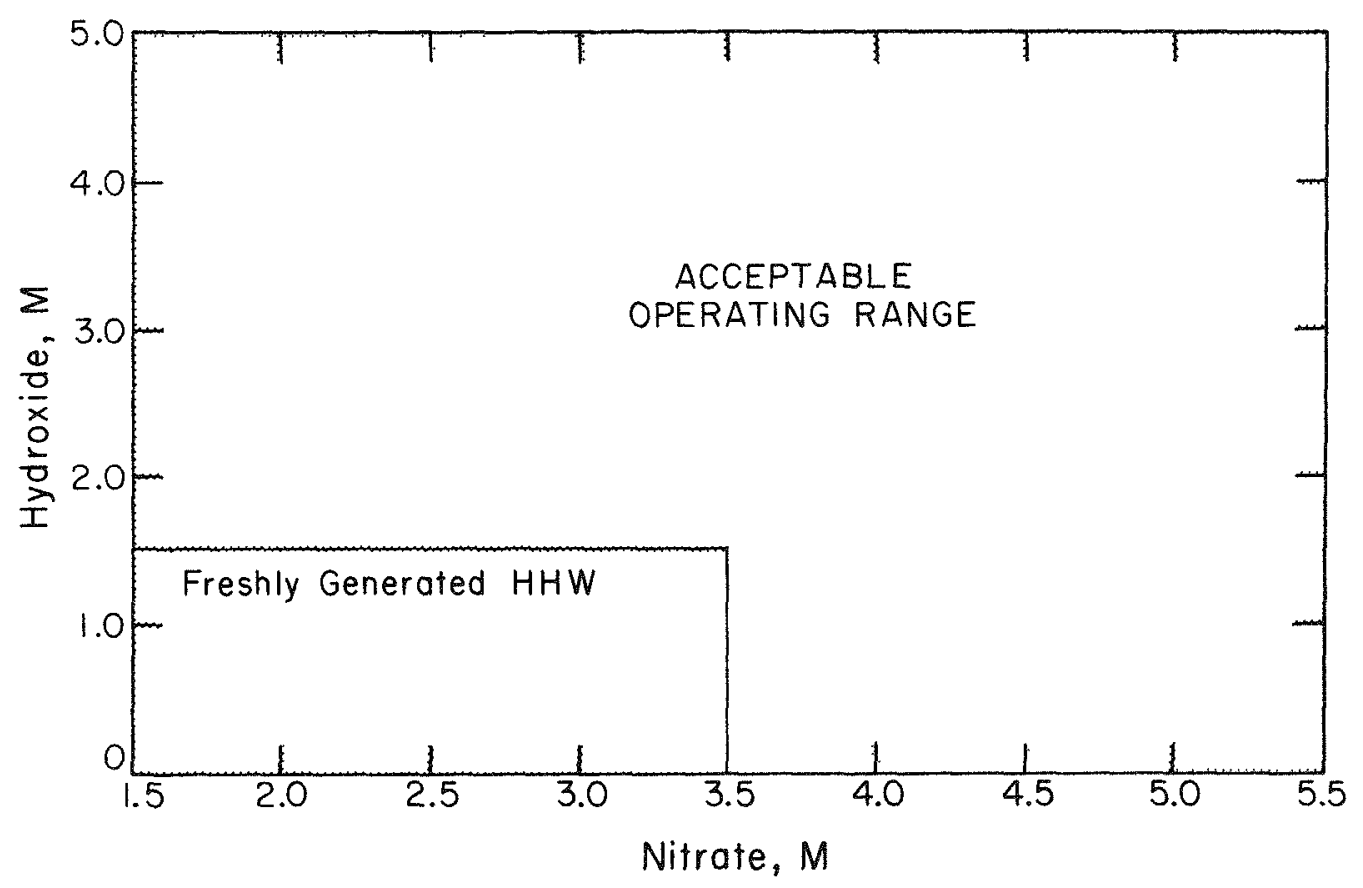

FIGURE 11. Operational Contour Map, $100^{\circ} \mathrm{C}, 0.0 \mathrm{M} \mathrm{NO}_{2}^{-}$

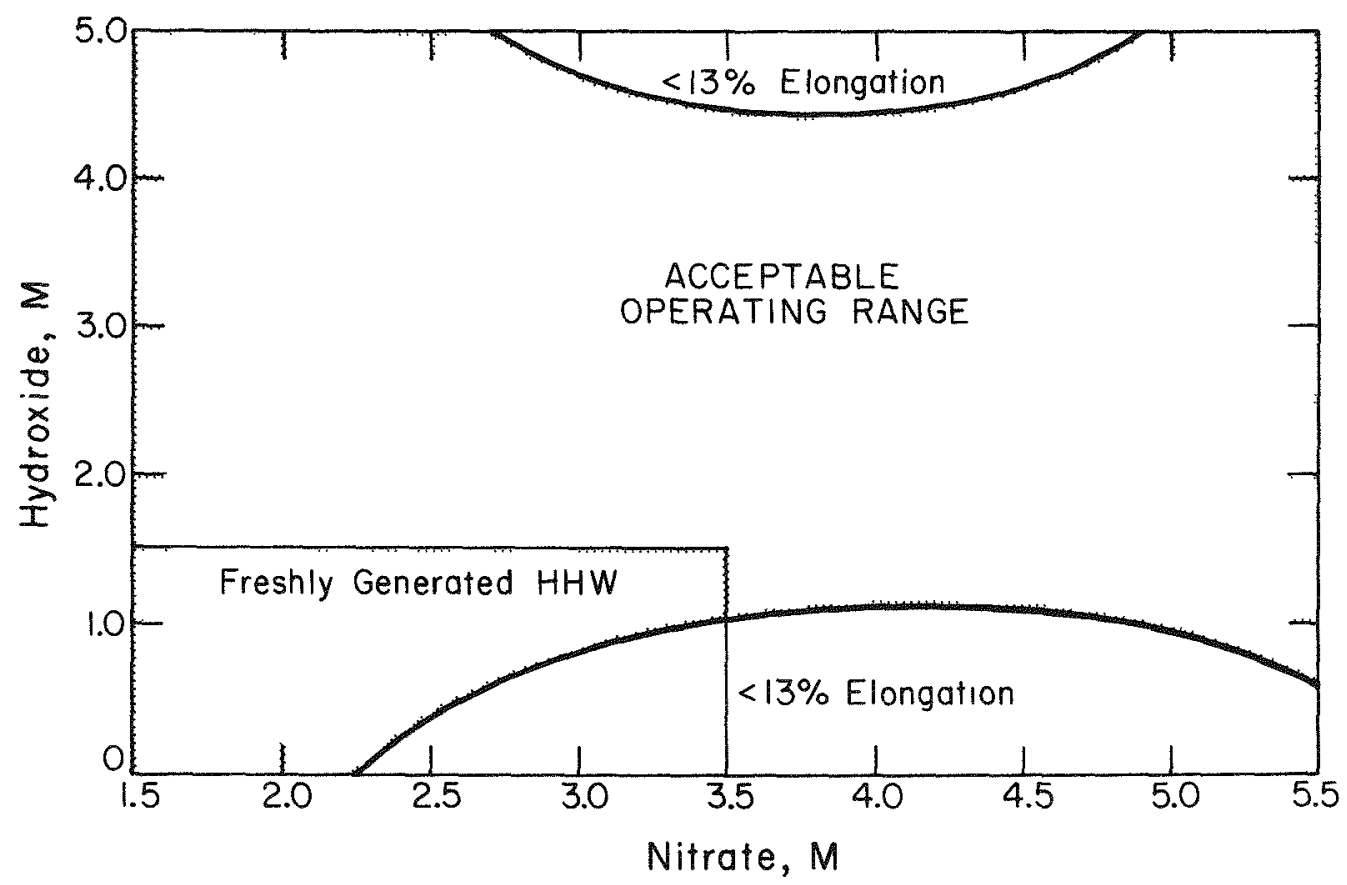

FIGURE 12. Operational Contour Map, $50^{\circ} \mathrm{C}, 0.0 \mathrm{M} \mathrm{N} \mathrm{N}_{2}^{-}$ 


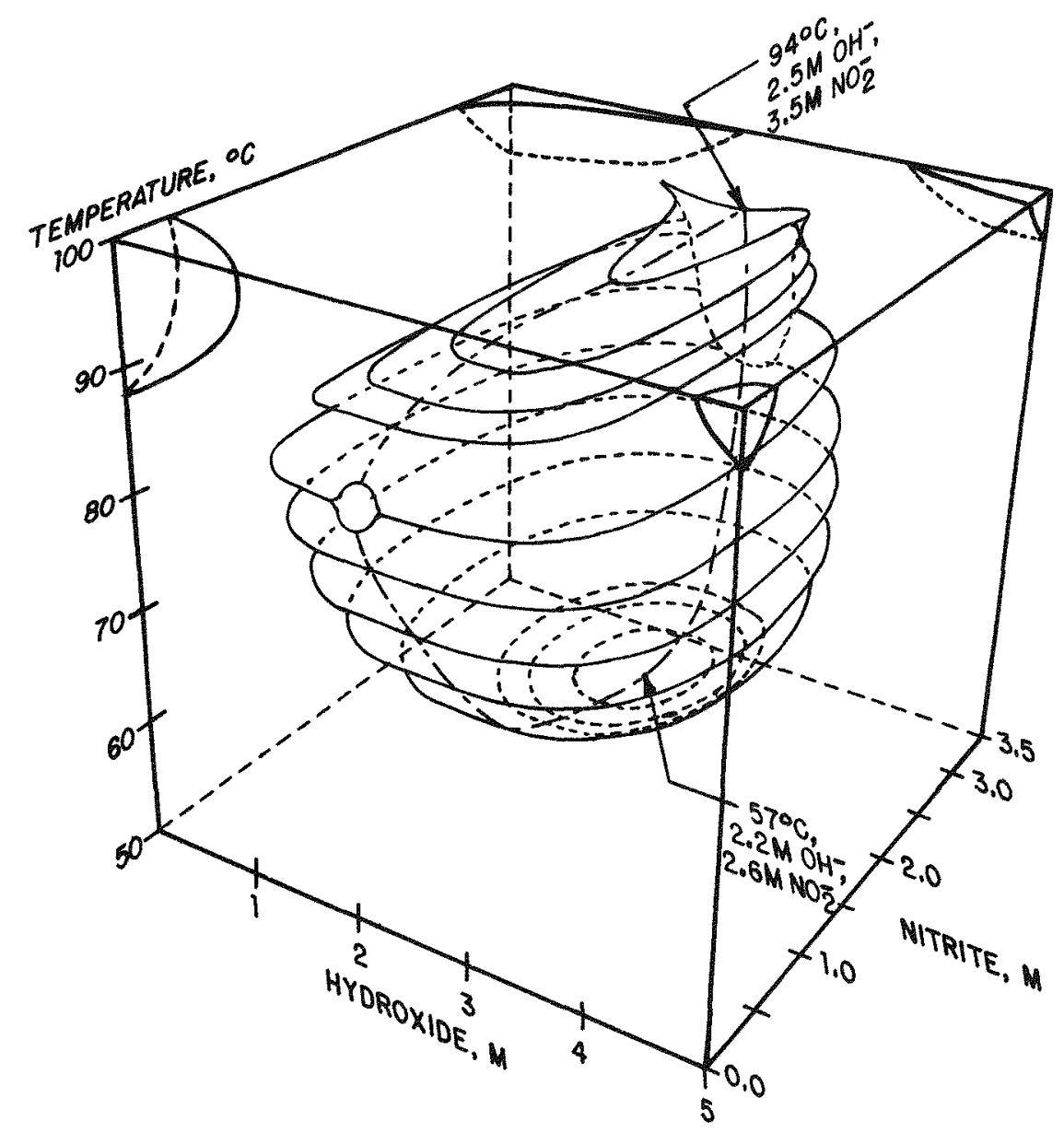

FIGURE 13. Equation 5 Depicted at $13 \%$ Elongation and $3.5 \mathrm{M} \mathrm{NO} \mathrm{NO}_{3}^{-}$ 
The low elongation at $75^{\circ} \mathrm{C}$ may be due to an effect of temperature on the solubilities of $\mathrm{O}_{2}$ perhaps combined with some other species in the solution. Corrosion of mild steel has been observed to be maximum at $80^{\circ} \mathrm{C}$, decreasing at both lower and higher temperatures. ${ }^{14}$ The higher temperatures decrease $\mathrm{O}_{2}$ solubility enough to decrease the corrosion rate, while at lower temperatures the corrosion rate also decreases because of a decrease in reaction rates. Smialowski and Ostrowska ${ }^{15}$ contend that $\mathrm{O}_{2}$ is of great importance in assisting the nitrate cracking mechanism, although Herzog and Portevin ${ }^{16}$ claim it is without effect. The differences in interpretation could be due to temperature and its effect on $\mathrm{O}_{2}$ solubility.

The presence of this region could be significant to waste operations. For example, Tanks 11 and 12, recently contained wastes of compositions that could lie within the enclosed volume. As shown in Figure 14 these solutions would produce an elongation of less than $13 \%$ at temperatures $>65^{\circ} \mathrm{C}$. However, the actual solution temperatures are $37^{\circ} \mathrm{C}$ for Tank 11 and $38^{\circ} \mathrm{C}$ for Tank 12, so the tanks will meet the $13 \%$ elongation criterion throughout the period of initial aging of the waste. When the contents are evaporated to reduce solution volume, the compositions will shift as shown and remain in a region with greater than $13 \%$ elongation.

\section{APPLICATIONS TO PLANT OPERATIONS}

\section{Interarea Transfers}

Transfer of wastes between areas is desirable to optimize HHW evaporator operations and waste tank utilization. Before these studies, the transfer of waste from $H$ to $F$ Area was considered to be inadvisable. H Area wastes were generally believed to be more aggressive than F Area wastes because of a much higher incidence of stress corrosion cracking in $\mathrm{H}$ Area.

A test sequence was developed to examine whether transfers from $\mathrm{H}$ Area to $\mathrm{F}$ Area should be made. The sequence included chemical analyses of the wastes, potentiodynamic polarization curves on the actual and synthetic wastes prepared on the basis of the chemical analysis, electrochemically controlled tensile tests, and wedge-opening loaded tests in synthetic waste solutions. Since the polarization curves were essentially identical, the steel would be expected to react the same way in synthetics and actual wastes. Electrochemically controlled tests determined susceptibility to crack initiation, wedge-opening loaded specimens determined susceptibility to crack propagation. 


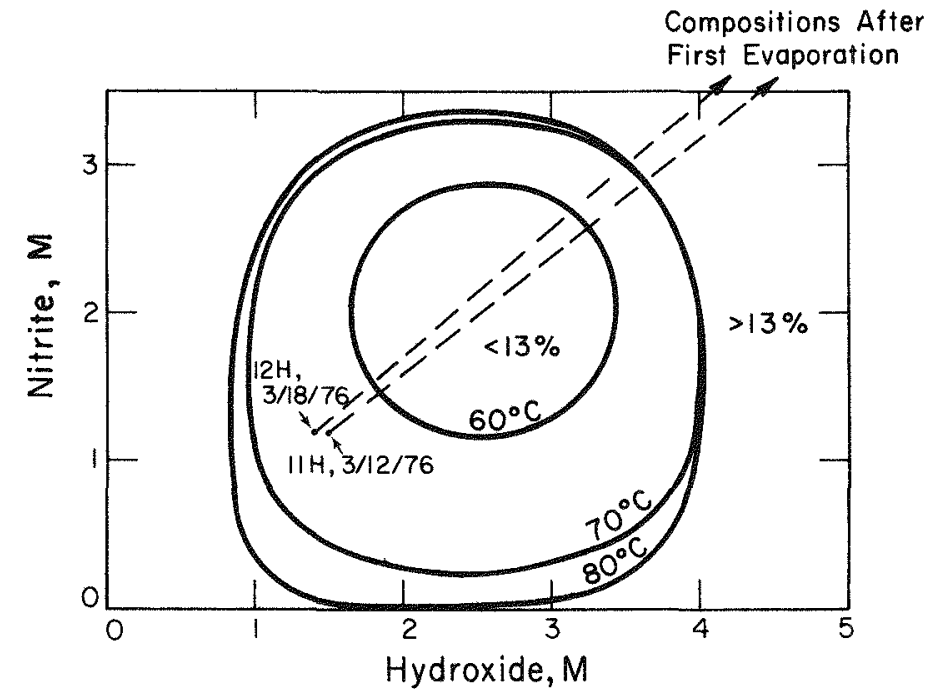

Waste Composition (Principal Anions Only)

Tank $\begin{aligned} & \text { Sample } \\ & \text { Date }\end{aligned}$

$11 \mathrm{H} \quad 3 / 12 / 76 \quad 4.0 \quad 1.5 \quad 1.2 \quad 0.6$

$\begin{array}{llllll}12 \mathrm{H} & 3 / 18 / 76 & 2.8 & 1.4 & 1.2 & 0.4\end{array}$

FIGURE 14. Waste Compositions in Tanks $11 \mathrm{H}$ and $12 \mathrm{H}$ Compared to $13 \%$ Elongation Boundaries; Contours at $4.0 \mathrm{M} \mathrm{NO}_{3}^{-}$ 
For the electrochemical tensile tests, the elongation values calculated from Equation 5 are compared with measured values in Table 9.

TABLE 9

Results of Electrochemical Tensile Tests at $100^{\circ} \mathrm{C}$

\begin{tabular}{|c|c|c|c|c|c|c|}
\hline \multirow[b]{2}{*}{ Tank } & \multicolumn{3}{|c|}{ Solution } & Total EZon & xtion, \% & \multirow{2}{*}{$\begin{array}{l}\text { Volume Transferred } \\
\text { From } H \text { to } F \text { Areas, gal. }\end{array}$} \\
\hline & $\overline{\mathrm{NO}_{3}}$ & $\mathrm{NO}_{2}^{-}$ & $\mathrm{OH}^{-}$ & Predicted & Measuredb & \\
\hline 11 & 3.6 & 1.2 & 1.5 & 16 & 17 & 413,000 \\
\hline 12 & 3.0 & 1.2 & 1.4 & 16 & 15 & Deferred $^{C}$ \\
\hline 13 & 3.7 & 0.26 & 1.4 & 14 & 16 & 496,000 \\
\hline 32 & 3.3 & 0.70 & 1.5 & 16 & 17 & $1,069,000$ \\
\hline
\end{tabular}

a. By Equation 5 .

b. Average of 2 values.

c. Transferred within H-Area.

The measured values were above the $13 \%$ elongation criterion. The average difference between the predicted and measured values for the four tests is $8 \%$ or about the error expected for a tensile test in air. The data provided a basis for approving the transfer of 2.0 million gallons of HHW from $H$ to $F$ Areas, as indicated in Table 9.

Recommended Limits for Liquid Wastes

The limits shown in Table 10 have been established for waste tank operations. The limits for high nitrate contents are based on the results of 1 ) electrochemical tensile test, which emphasize conditions for crack initiation and 2) results from studies using wedge-opening-loaded (WOL) specimens. WOL specimens were used to evaluate conditions which cause crack propagation. Data for both methods are summarized in Figure 15. Note that good agreement exists for the two approaches in that compositions that cause cracks to form also cause them to grow. 
The required minimum $\mathrm{OH}^{-}$and $\mathrm{NO}_{2}^{-}$concentrations are reduced at lower $\mathrm{NO}_{3}^{-}$contents in keeping with the result from the present study, Figure 8. For example, below $1 \mathrm{M} \mathrm{NO}_{3}^{-}$nitrate stress cracking does not occur; ${ }^{7}$ the minimum $\mathrm{OH}^{-}$content of $0.01 \mathrm{M}$ is specified to prevent pitting attack.

The maximum temperature of $70^{\circ} \mathrm{C}$ is the lowest value that can normally be maintained in the tanks during storage of fresh wastes because of their relatively high heat generation. Low temperatures are generally desirable because they reduce corrosion reaction rates. After evaporation the wastes are returned from the evaporator at nearly the boiling point. Since the concentrations of $\mathrm{OH}^{-}$and $\mathrm{NO}_{2}^{-}$are then quite high, 2.5 to $3.5 \mathrm{M}$ for $\mathrm{NO}_{2}^{-}$, no corrosion damage should result because of the higher temperatures.

TABLE 10

Recommended Limits for Liquid Wastes

$\mathrm{NO}_{3}^{-}$in 1 iquid phase of Minimum Maximum concentrated waste

$\mathrm{OH}^{-}+\mathrm{NO}_{2}^{-}$in liquid phase of concentrated waste

For $\mathrm{NO}_{3}^{-} 3.0$ to 5.5

$$
\mathrm{OH}^{-}
$$

For $\mathrm{NO}_{3}^{-} 1.0$ to 3.0

$$
\begin{array}{ll}
\mathrm{OH}^{-} & 0.1\left[\mathrm{NO}_{3}^{-}\right] \\
\mathrm{OH}^{-}+\mathrm{NO}_{2}^{-} & 0.4\left[\mathrm{NO}_{3}^{-}\right]
\end{array}
$$

For $\mathrm{NO}_{3}^{-}<1.0$

$\mathrm{OH}^{-}$

Temperature of 1 iquid phase

Fresh waste solutions

Concentrated wastes
$0.01 \mathrm{M}$

$(\mathrm{pH}=12)$ 


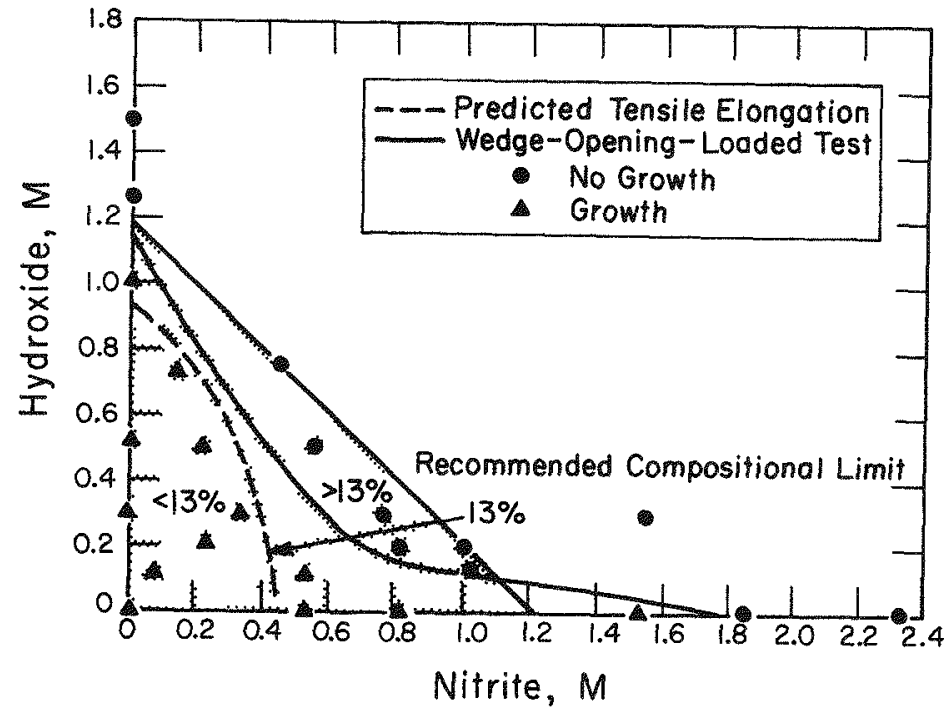

FIGURE 15. Comparison of Electrochemical Tensile Test With WedgeOpening-Loaded Specimens in $5 \mathrm{M} \mathrm{NaNO}$ at $97^{\circ} \mathrm{C}$ 


\section{REFERENCES}

1. Plan for the Management of Radioactive Waste, Savannah River PZant. USERDA Report SRO-TWM-75-1, Savannah River Operations Office, Aiken, SC (1975).

2. R. S. Ondrejcin. Chemical Compositions of Supernates Stored in SRP High Activity Waste Tanks. USAEC Report DP-1347, E. I. du Pont de Nemours \& Co., Aiken, SC (1974).

3. T. P. Hoar and J. R. Galvele. "Anodic Behavior of Mild Stee1 During Yielding in Nitrate Solutions." Corros. Sci. 10, 211 (1970).

4. G. Sandoz, C. T. Fujii, and B. F. Brown. "Solution Chemistry Within Stress-Corrosion Cracks in Alloy Steels." Corr. Sci. 10, 839 (1970).

5. R. N. Parkins and R. Usher. "The Effect of Nitrate Solutions in Producing Stress-Corrosion Cracking in Mild Stee1." 289 in First International Congress on Metallic Corrosion, Butterworths, London (1962).

6. R. A. Legault, S. Mori, and H. P. Leckie. "An Electrochemical Statistical Study of the Effect of Chemical Environment on the corrosion Behavior of Mild Steel." Corrosion 6, 121 (1970).

7. R. N. Parkins. "Stress Corrosion Cracking of Low Carbon Steels." 361 in Proceedings of Conference on Fundamental Aspects of Stress Corrosion Cracking, Sept. 11-15, 1967 at Ohio State University, Columbus, OH. National Assoc. of Corr. Eng., Houston, TX (1969).

8. R. M. Girdler. Leaks in Radioactive-Waste Tanks. USAEC Report DP-990, E. I. du Pont de Nemours \& Co., Savannah River Laboratory, Aiken, SC (1965).

9. R. L. P1ackett and J. P. Burman. "The Design of Optimum Multifactorial Experiments." Biometrica 33, 305 (1946).

10. G. E. P. Box and D. W. Behnkin. "Some New Three Level Designs for the Study of Quantitative Variables." Technometrics 2, 455 (1960). 
11. R. N. Parkins. "Stress Corrosion Cracking of Low Carbon Steels." p. in Proceedings on Fundamental Aspects of Stress Corrosion Cracking, Ohio State University, Columbus, OH. National Assoc. of Corr. Eng., Houston, TX (1969).

12. M. Smialowski. "Discussion." p. 295 in First Intermational Congress on Metallic Corrosion, Butterworths and Co., London (1961).

13. J. A. Donovan. "Inhibition of Nitrate Stress Corrosion Cracking of Mild Steel in Nuclear Process Wastes." Trans. Am. Nucl. 21, 266 (1975).

14. H. H. Uhlig. Corrosion and Corrosion Control. 2nd ed., John Wiley \& Sons, New York, NY (1971).

15. M. Smialowski and T. Ostrowska. "Mechanism of Intercrystalline Corrosion of Mild Steel by Ammonium Nitrate." Corr. et Anticorr. 5, 76 (1957).

16. E. Herzog and M. Portevin. "Sur 1a corrosion fissurante d'aciers doux a faibles teneurs en additions dars les nitrates." Metaux et Corrosion 24, 40 (1949). 


\section{DISTRIBUT ION}

Copy

No.

1-3. DOE-SR, Aiken, SC

4-49. Du Pont Co., Aiken, SC

50-301. TIC, Oak Ridge, TN 